\title{
The Mutation of International Law in Contemporary Constitutions: Thinking Sociologically about Political Constitutionalism
}

DOI:

10.1111/1468-2230.12177

\section{Document Version}

Final published version

Link to publication record in Manchester Research Explorer

Citation for published version (APA):

Thornhill, C. (2016). The Mutation of International Law in Contemporary Constitutions: Thinking Sociologically about Political Constitutionalism. The Modern Law Review, 79(2), 207-247. https://doi.org/10.1111/14682230.12177

\section{Published in:}

The Modern Law Review

\section{Citing this paper}

Please note that where the full-text provided on Manchester Research Explorer is the Author Accepted Manuscript or Proof version this may differ from the final Published version. If citing, it is advised that you check and use the publisher's definitive version.

\section{General rights}

Copyright and moral rights for the publications made accessible in the Research Explorer are retained by the authors and/or other copyright owners and it is a condition of accessing publications that users recognise and abide by the legal requirements associated with these rights.

\section{Takedown policy}

If you believe that this document breaches copyright please refer to the University of Manchester's Takedown Procedures [http://man.ac.uk/04Y6Bo] or contact uml.scholarlycommunications@manchester.ac.uk providing relevant details, so we can investigate your claim.

\section{OPEN ACCESS}




\section{THE \\ MODERN LAW REVIEW}

Volume 79

March 2016

No. 2

\section{The Mutation of International Law in Contemporary Constitutions: Thinking Sociologically about Political Constitutionalism}

\section{Chris Thornhill*}

This article proposes a sociological critique of theories of political constitutionalism, which distinguish sharply between political and judicial constitutionalism and express hostility towards constitutions allowing extensive judicial control of legislation. It argues that such theories are usually undermined by a sociologically deficient account of politics. As an alternative, this article proposes a theory of politics based in a model of systemic inclusion. Using this perspective, it claims that constitutions with a strong judicial emphasis, especially where judicial functions are supported by international norms, have served, in many societies, as an effective precondition for the emergence and persistence of a relatively secure, differentiated political domain. These claims are exemplified through analysis of recent constitution-making experiments in Russia, Kenya and Bolivia.

\section{JUDICIAL CONSTITUTIONALISM AND ITS CRITICS}

The contemporary democratic state has widely assumed a constitutional form which is very different from that envisaged by the original theorists and architects of democratic constitutional law. We can in fact identify a distinctive model of constitutional order, which is now characteristic of contemporary society, and which has little in common with classical patterns of constitutional legislation. Some features of this model are traceable to constitution arrangements created in Central Europe during and in the years after the dissolution of the Habsburg Empire. ${ }^{1}$ More broadly, however, the currently dominant model of constitutionalism has been defined through processes of democratic transition and systemic transformation, conducted in societies with a recent

* School of Law, University of Manchester. Research for this article was funded by the European Research Council (Advanced Grant: 323656-STC). A very preliminary version of this article was presented at a Modern Law Review workshop on 'Constitutionalism(s) post 2008', held at the University of Warwick in June 2014.

1 See T. Olechowski, 'The Beginnings of Constitutional Justice in Europe' in M. Rask Madsen and C. Thornhill (eds), Law and the Formation of Modern Europe. Perspectives from the Historical Sociology of Law (Cambridge: CUP, 2014) 77. 
history of political authoritarianism. ${ }^{2}$ This model was initially elaborated in the post-authoritarian democracies established after 1945. Then it was reproduced in the Iberian and Latin American transitions of 1970s and 1980s, and it was further fleshed out in the Eastern European transitions and processes of transformation in the late 1980s and early 1990s. It was eventually transplanted into many states that underwent regime transformation in Sub-Saharan Africa through the 1990s and beyond. Although mainly forged in states undergoing systemic restructuring, though, this model is not restricted to states that have recently experienced democratic or quasi-democratic re-foundation. In fact, the general pattern of contemporary constitutionalism has clearly begun to penetrate and transform more established democratic polities, such as the UK and France. ${ }^{3}$

Across quite different lines of constitutional formation and construction, consequently, we can observe that contemporary constitutions are usually defined, either fundamentally or by incremental tendency, by the following characteristics: (1) greater power is accorded to courts and to the judicial branch in general than was the case in classical constitutionalism; (2) high courts, armed with strong powers of judicial review, are permitted to pre-define the content of the law, and to place constraints on the decisions of actors with legislative authority; (3) national courts usually derive their authority in part from the salience accorded to international law, and courts acquire the power to shape legislation because they scrutinise national laws in light of internationally defined norms, especially norms protecting human rights, within domestic polities; (4) the interaction between national and international judicial bodies stands at the origin of, and partly defines the scope of, legitimate legislative power, and primary norms in domestic law are constructed, at least in part, on the foundation of international law.

Overall, in short, contemporary constitutions are marked, almost generically, by a rise in judicial power, and, closely linked to this, by the intensified penetration of international law into domestic legal systems. ${ }^{4}$ In general terms, most contemporary societies, albeit with important outliers, promote a system

2 In most cases of recent political restructuring, systemic transformation seems a more accurate description than the more usual term: transition. For related claims see T. Carothers, 'The End of the Transition Paradigm' (2002) 13 Journal of Democracy 5, 13.

3 See, for select comment, F. Fabbrini, 'Kelsen in Paris: French Constitutional Reform and the Introduction of a posteriori Constitutional Review of Legislation' (2008) 9 German Law Journal 1297; A. L. Young, 'Judicial Sovereignty and the Human Rights Act 1998' (2001) 61 Cambridge Law Journal 53, 65; N. Bamforth and P. Leyland, 'Public Law in a Multi-Layered Constitution' (2003) 8 Judicial Review 157, 161; M. Sunkin, 'Judicialization of Politics in the United Kingdom' (1994) 15 International Political Science Review 125; A. Stone Sweet, 'The Constitutional Council and the Transformation of the Republic' (2008) 79 Yale Law School Faculty Scholarship Series; A. Kavanagh, Constitutional Review under the UK Human Rights Act (Cambridge: CUP, 2009) 275.

4 To be clear, the rising constitutional standing of courts was not originally directly and expressly linked to the authority of international norms within national legal systems. From the outset, however, there was always a strong implied connection between constitutional review and the openness of domestic legal systems to international law. After 1918, Kelsen's Austrian constitution of 1920 was in part shaped by the idea that one system of norms could pervade society in its entirety, with international law as the highest source of such norms. See H. Kelsen, Das Problem der Souveränität und die Theorie des Völkerrechts: Ein Beitrag zu einer reinen Rechtslehre (Tübingen: 
of public-legal order, which can be classified as judicial constitutionalism or even transnational judicial constitutionalism.

At the centre of this new model of constitutionalism are two distinctive principles, which set it apart from classical constitutional ideals. Most obviously, constitutions close to this model are not sustained, in the classical sense implied by Georg Jellinek, by reference to a single unified national people. Many normative elements of judicial constitutionalism are reproduced from a nationally overarching legal system, and they are moved from one polity to another, often without declared national-popular authorisation. As a result, secondly, constitutions close to this model cannot be seen to channel a clear political will through state institutions, and they do not derive founding legitimacy for legal acts from primary expressions of popular volition or constituent power. ${ }^{5}$ In its distinction from classical constitutionalism, unsurprisingly, the contemporary pattern of judicial constitutionalism has been widely criticised. In particular, it has been condemned as anti-democratic: it has been derided both as a legal order that uses judicial norms illegitimately to constrain acts of national self-determination, ${ }^{6}$ and as a legal order that holds democratic agents in national societies in thrall to the interests of international hegemonic actors. ${ }^{7}$ In addition, it has been criticised for its allegedly anti-political character. ${ }^{8}$ The fact that in the judicial constitutional model some authority is transferred from elected legislatures to unelected courts, and that strong entrenchment is provided for supranational

Mohr, 1920) 215. After 1945, constitutional review, the rise of constitutional courts, and the commitment to direct domestic application of international law were common features of new democracies. In West Germany, tellingly, the Constitutional Court was defined as a transformer of international human rights law, see H. Mosler, Das Völkerrecht in der Praxis der deutschen Gerichte (Karlsruhe: Müller, 1957) 25. In more recent examples, the growth of judicial power in domestic constitutions is almost invariably linked to increasingly monistic constructions of constitutional law. Even in the UK, the rising audacity of judicial actors in reviewing public acts is usually bolstered by the rising authority accorded to international conventions. See for example Ahmed and others v Her Majesty's Treasury (JUSTICE intervening) (Nos 1 and 2); al-Ghabra v Same (Same intervening); Regina (Youssef) v Same (Same intervening) [2010] 2 AC 534. In fact, some of the earliest justifications of judicial review of primary laws, set out in the first decades of the American Republic, were closely flanked by a domestic incorporation of international norms. See J. P. Paust, International Law as Law of the United States (Durham, NC: Carolina Academic Press, $2^{\text {nd }}$ ed, 2003) 7.

5 P. Dobner, Konstitutionalismus als Politikform. $\mathrm{Zu}$ den Effekten staatlicher Transformation auf die Verfassung als Institution (Baden-Baden: Nomos, 2002) 212.

6 D. Grimm, Die Zukunft der Verfassung (Frankfurt am Main: Suhrkamp, 1991) 31.

7 See R. Hirschl, 'The New Constitutionalism and the Judicialization of Pure Politics Worldwide' (2007) 75 Fordham Law Review 721, 723. More generally, see, R. Hirschl, Towards Juristocracy. The Origins and the Consequences of the New Constitutionalism (Cambridge, Mass: Harvard University Press, 2004); J. Ferejohn, 'Judicializing Politics, Politicizing Law' (2002) 65 Law and Contemporary Problems 41, 41, 44; D. Schneiderman, Constitutionalizing Economic Globalization. Investment Rules and Democracy's Promise (Cambridge: CUP, 2008); D. Nicol, The Constitutional Protection of Capitalism (Oxford and Portland, Or: Hart, 2010) ch 4; B. S. Chimni, 'Third World Approaches to International Law: A Manifesto' (2006) 8 International Community Law Review 3, 8-11.

8 This claim arises partly because judicial constitutionalism is associated with international economic interests, subjecting national polities to irresistible override. But it also rephrases the classical critique of judicial control of statutes as an unmandated ex ante constraining of the popular will. For this view, legitimate law is only 'a set of norms that have been formulated and thus willed by the people', M. Troper, 'The Logic of Justification of Judicial Review' (2003) 1 International Journal of Constitutional Law 99, 116. 
rights, which filter the social interests that can be channelled through elected legislatures, means that it is commonly contrasted, often critically, with political constitutionalism. Political constitutionalism is also, of course, rather variable in form. But adherents of political constitutionalism usually present it as an outlook that endorses more classical processes of democratic constitutional organisation. In political constitutionalism, typically, public law is expected to originate in some expression of constituent power, ${ }^{9}$ fixed counterweights to the exercise of popular power (especially if these counterweights are of international provenance) have less influence, inner-societal demands and conflicts are directed more openly through the political system, and the legislative branch of the political system is directly accountable to a represented public will. ${ }^{10}$

The critical distinction between political constitutionalism and legal or judicial constitutionalism is especially prominent in the context of British constitutional debate. In Britain, the rise of judicial power touches a very vulnerable constitutional nerve, and it threatens to weaken, or even permanently to reform, the historically inviolable sovereignty of the parliamentary legislature. From this British perspective, the political constitution is imperilled by the following features of judicial constitutionalism: the rising force of international law, especially international human rights law, including the European Convention on Human Rights (ECHR); the judicial application of human rights norms to elevate certain statutes above normal parliamentary power; ${ }^{11}$ the spread of proportionality as a principle of jurisprudence ${ }^{12}$ and the general hubris of democratically unmandated judicial bodies. ${ }^{13}$ However, the political

9 M. Loughlin, 'The Concept of Constituent Power' (2013) 13 European Journal of Political Theory $218,234$.

10 A large volume of literature on political constitutionalism relates particularly to the UK polity. See the classical view that 'law is not and cannot be a substitute for politics' in J. A. G. Griffith, 'The Political Constitution' (1979) 42 Modern Law Review 1, 16. There are other more recent cases of insistence on the necessity of an irreducibly political moment in constitutionalism, derived from the realised public will of the people. See for example M. Loughlin, Foundations of Public Law (Oxford: OUP, 2010); R. Bellamy, Political Constitutionalism. A Republican Defence of the Constitutionality of Democracy (Cambridge: CUP, 2007). Pervasive through these accounts is the idea that a political constitution is immediately responsive to public will formation, and is thus 'a direct expression of ordinary political activity within and across political institutions ... in a way that makes explicit the possibility of adaptation, and even radical adaptation, through such ordinary, day-to-day political activity', G. Gee and G. C. N. Webber, 'What is a Political Constitution?' (2010) 30 Oxford Journal of Legal Studies 273, 288. For a balanced alternative to the stark distinction between legal and political constitutionalism see A. Tomkins, 'What's Left of the Political Constitution?' (2013) 14 German Law Journal 2275, 2290.

11 On the principle that the British constitution might now entertain the idea that there are now constitutional fundamentals "which even a sovereign Parliament acting at the behest of a complaisant House of Commons cannot abolish', see the opinion of Lord Steyn in $R$ (Jackson) $v$ Attorney General [2005] All ER 136. For general comment see R. Masterman, 'Taking the Strasbourg Jurisprudence into Account: Developing a "Municipal Law of Human Rights" under the Human Rights Act' (2005) 54 International Law and Comparative Law Quarterly 907, 913.

12 See the key example in R v Secretary of State for the Home Department, ex $p$ Daly [2001] UKHL 26.

13 See, as exemplification of judicial opinions on the changing constitution, International Transport Roth GmbH and Ors v Secretary of State For the Home Department [2002] EWCA Civ 158, 71. For critical discussion and a sketch of the main issues see P. Craig, 'Political Constitutionalism and the Judicial Role: A Response' (2011) 9 International Journal of Constitutional Law 112. 
critique of legal or judicial constitutionalism is not nationally localised, and it is evident in a variety of different national and historical settings. Across the boundaries between different constitutional traditions, the sense that contemporary constitutionalism effects a move away from substantially political constructions of constitutional legitimacy is quite generalised. The origins of this claim can in fact be found, in a number of nations, in arguments around the development and progressive growth of constitutional review as a means of legislative control. ${ }^{14}$ The contemporary rise of judicial constitutionalism, and its contrast with political constitutionalism, thus gives acute expression to a body of long-standing, diverse, and cross-national theoretical controversies. This has led to the emergence of a broad and rather eclectic front of constitutional theorists, who, for different reasons, denounce the judicial bias of contemporary constitutionalism in the name of a defence of the political substance of society, often invoking theories of political conflict and contested will formation as the foundation for their rejection of judicial power. ${ }^{15}$ Underlying the work of these theorists - however distinct in their own right - is the perception that the

14 Both periods of classical constitution making, revolutionary America and revolutionary France, expressed reservations about raw judicial power. After the American Founding, note Jefferson's hostility to judicial power, which he saw as turning the constitution into a 'thing of wax'. See Thomas Jefferson, 'Letter to Judge Spencer Roane, 6.9.1819' in T. Jefferson, Writings (New York: Library of America, 1984) 1425, 1426. Of course, the debate about limits of judicial review in the USA has raged from the Revolution to the present (see n 17 below). Note, in parallel to this, the broad hostility to judicial review in revolutionary France, where courts were associated with the corrupt corporate power of the parlements of the ancien régime. See H. Carré, La fin des parlements (Paris: Hachette, 1912); L. Jaume, Le discours Jacobin et la démocratie (Paris: Fayard, 1989) 50. The classical political critiques of judicial power and resultant defence of political constitutionalism gained particular impetus in the Weimar Republic, whose volatile theoretical controversies provided the foundations for many current constructions of politics. For the most famous example, see C. Schmitt, Der Hüter der Verfassung (Berlin: Duncker und Humblot, 1931). Panu Minkkinen is clearly right to insist on a distinction between British political constitutionalism and what he terms Schmittian 'political constitutional theory': P. Minkkinen, 'Political Constitutionalism versus Political Constitutional Theory: Law, Power, and Politics' (2013) 11 International Journal of Constitutional Law 585. Nonetheless, for all the general validity of Minkkinen's claims on this point, Schmitt can surely be invoked as a precursor of contemporary critiques of judicial politics. In the Weimar context, note the alternative, more tentative, distinction between political and judicial questions in $\mathrm{H}$. Triepel, 'Bericht: Wesen und Entwicklung der Staatsgerichtsbarkeit' in H. Triepel, M. Layer and E. von Hippel, Wesen und Entwicklung der Staatsgerichtsbarkeit. Überprüfung von Verwaltungsakten durch die ordentlichen Gerichte (Berlin: de Gruyter, 1929) 2, 26. Triepel concluded that there is always a contradiction between the political core of the constitution and the technical procedure of judicial review (ibid, 6). Tellingly, Triepel was keen to accentuate the power of the higher courts. He saw functions of judicial review as leading to beneficial 'reinforcement of legal sense', which weakened the power of the elected Reichstag: H. Triepel, 'Streitigkeiten zwischen Reich und Ländern. Beiträge zur Auslegung des Artikels 19 der Weimarer Verfassung' in T. Kipp and H. Triepel (eds), Festgabe der Berliner Juristischen Fakultät für Wilhelm Kahl (Tübingen: Mohr, 1923) 115. Often neglected in the contemporary reception of interwar German and Austrian Staatslehre is the work of Leo Wittmayer, who expressly - and affirmatively - saw the role of basic rights in the constitutional state as producing a necessary and salutary depoliticisation of the political system. See L. Wittmayer, Reichsverfassung und Politik (Tübingen: Mohr, 1923) 8.

15 The theory of politics as conflict unifies different lines in the critique of court-directed politics. This was already clear enough in the works of Schmitt, who placed conflict close to the centre of his account of the political. See C. Schmitt, Der Begriff des Politischen (Berlin: Duncker und Humblot, 1932) 26-29. But similar views have been detected in the British tradition of antijudicialism, see G. Gee, 'The Political Constitutionalism of JAG Griffith' (2008) 28 Legal Studies 
immediate democratic provenance of law is a vital indicator of its legitimacy. To secure such legitimacy, the process of law production cannot be occluded - say, by judiciaries, international bodies, or formal bills of rights - against the particular dynamics of social contestation. Legitimate politics, in other words, must necessarily reflect, and mediate between, diverse positions in the spectrum of social conflict, dissent or deliberation, and it must articulate a shared will resulting from such conflict or deliberation, placing decisions made by institutions accountable to society as a whole (legislatures, parliaments) above those made by judges or courts. ${ }^{16}$ Underlying the work of these theorists, further, is the view, conventional in both constitutional theory and the classical theory of international law, that judicial power, and especially judicial power enforcing basic rights or human rights, restricts the political dimension of society, and it places static, formal limits on the capacity of a society for articulating a distinct sovereign political will. ${ }^{17}$

One purpose of this article is to make a sociological contribution to debates surrounding the distinction between political and legal or judicial constitutionalism, and to re-examine the core claims of different contributions to these debates by transposing analysis of judicial constitutionalism into a sociological framework. In particular, this article argues that the debates outlined above have, to date, been conducted in something close to a sociological vacuum, showing only limited consciousness of the material forces driving the rise of the legal or judicial constitution across different societies. ${ }^{18}$ As a result, theories expressing a preference for one or other model of constitutionalism do so without appreciation of the reasons why certain patterns of constitutional normativity have evolved, and without recognising how particular constitutional norms are correlated with broader social processes. Such expressions of theoretical preference thus tend to be reductive, socially abstracted, and evidentially questionable. This article seeks to rectify this sociological deficit by examining the emergence of judicial constitutionalism in a number of different political systems, and by assessing the sociological motivations and societal pressures which, in different concrete socio-historical contexts, have shaped the growing judicial emphasis of constitutional law. In this respect, the sociological

20, 27. Theories of deliberative politics are also underpinned by ideas of politics as an essentially antagonistic domain of human action.

16 R. Bellamy, 'Political Constitutionalism and the Human Rights Act' (2011) 9 International Journal of Constitutional Law 86, 91-92; J. Waldron, 'The Core of the Case against Judicial Review' (2006) 115 Yale Law Journal 1346, 1349.

17 For samples of this view in constitutional law, see M. Tushnet, Taking the Constitution Away from the Courts (Princeton, NJ: Princeton University Press, 1999) 9; L. D. Kramer, The People Themselves. Popular Constitutionalism and Judicial Review (Oxford: OUP, 2004) 233. For samples of this view in (otherwise often counter-posed) reflections on international law see P. C. Jessup, 'The Subjects of a Modern Law of Nations' (1947) 45 Michigan Law Review 383, 406; R. Falk, The Status of Law in International Society (Princeton, NJ: Princeton University Press, 1970) xiii; J. Delbrueck, 'International Protection of Human Rights and State Sovereignty' (1982) 57 Indiana Law Journal 567, 572; J. A. Rabkin, Law without Nations? Why Constitutional Government requires Sovereign States (Princeton, NJ: Princeton University Press, 2007) 70.

18 To qualify this claim a little, both Hirschl and Schneiderman could be seen as using a sociological method, broadly defined. But the new pattern of constitutional democracy is not an eminent object of sociological reconstruction. 
approach to current patterns of constitution making promoted here is intended to add a dimension of empirical sociology to debate about legal and political constitutionalism, and it invites legal and political theorists to test their analyses through a material reconstruction of constitutional law and the social settings in which it evolves.

Most importantly, however, the claims set out in this article are shaped by the sense that, owing to its sociological under-reflection, the defence of political constitutionalism is badly let down by its rather conventionalised, even simplified, use of its core concept: politics. In consequence of this, proponents of political constitutionalism typically fail to explain what is specifically political in their favoured version of constitutional order, and their account of politics struggles to withstand serious sociological scrutiny. As mentioned, the description of the eminently political element in political constitutionalism is usually left to repose on rather unchallenged presumptions, associating the political dimension of society and its laws with the direct expression of social contest, with the close nexus between legislation and express societal demands, and with institutions based in democratic will formation. ${ }^{19}$ The sociological outlook proposed in this article, however, challenges these presuppositions. It argues for a more sociologically reflected understanding of politics, and of the political content of a society more widely, and it uses a macro-sociological perspective to observe ways in which, in different societies, certain interactions have been constructed as generically and categorically political. On this basis, this article claims that the political content of a society cannot be uniformly defined, it cannot be attributed to simple or uniform patterns of agency, contest, or organisation, and it depends, instead, on highly uncertain, contingent processes of social formation and systemic abstraction. Many societies have in fact been marked by a deep, easily reversible, and endemically unsettling struggle to construct a particular sphere of interaction as meaningfully political, and, in many cases, societies have been forced to devise unusual measures to harden a domain of strictly political exchange and to insulate this domain against fragmentation. Politics, in short, is not a sociologically given or an anthropologically invariable part of human society, and there is no political substrate for constitutional law which can be imputed to all societies. Politics is understood here, sociologically, as a structure of inclusion, in which societies, over time, acquire the capacity to set some norms and some collective functions apart from everyday processes of social contestation, and in which decisions are produced which can be plausibly explained and justified, and so

19 Note here that some researchers have attempted to integrate the procedures of judicial review into a larger theory of deliberative politics or even of legislative sovereignty. See for examples C. R. Zürn, Deliberative Democracy and the Institutions of Judicial Review (Cambridge: CUP, 2007) 264; R. Post and R. Siegel, 'Popular Constitutionalism, Departmentalism, and Judicial Supremacy' (2004) 92 California Law Review 1027, 1035; S. Freeman, 'Constitutional Democracy and the Legitimacy of Judicial Review' (1990) 9 Law and Philosophy 327, 360. Such perspectives obviously differ from more typical lines of political constitutionalism. However, they also ultimately predicate their concept of politics on residual experiences of conflict, and its discursive mediation, to which they see jurisprudence and review functions of courts as able to contribute. My argument, however, implies that judicial review, especially judicial review reflecting international norms, is often, simply, a precondition for politics. 
have a reasonable chance of gaining compliance, across the divergent sectoral, functional, and geographical fields that a society contains. ${ }^{20}$ On this definition, politics is a structural dimension of society, on which society relies for the authoritative generalisation of certain norms, and which forms a precondition for the positive production and evenly inclusive application of law. In many cases, however, societies have experienced limited success in abstracting an inclusionary structure of this kind, and their ability to designate some norms, procedures and decisions as political has long remained precarious. Political constitutionalism, therefore, needs to be seen in this context: a constitution is determinately political, not if it ensures a correlation between government and people, but if it contributes to the abstraction and preservation of a general structure of inclusion for a particular society. In the sociological understanding of politics presented here, above all, the commonly posited antinomy between legal and political constitutionalism becomes deeply questionable.

\section{JUDICIAL CONSTITUTIONALISM AND ITS SOCIAL FOUNDATIONS}

There are some general features in the background to the recent rise of legal or judicial constitutionalism which are not commonly analysed, but which have great relevance for the debates about the supposedly apolitical or antipolitical character of such constitutionalism. Observation of these features casts serious doubt on the common counter-position between political and judicial constitutionalism. Striking in this regard, above all, is the fact that in most societies the rise of constitutions with a strong rights-based, judicial emphasis has been closely linked to a crisis of corporatist constitutionalism. In most cases, the emergence of a constitutional order with a strong judicial dimension has formed a reaction to the collapse of constitutions designed to mobilise legitimacy for the state by corporate mechanisms. That is to say, judicial constitutionalism has typically replaced constitutions committed to the active integration of originally private economic associations and interest organisations (eg, trade unions, lobbies, cartels, peak associations) in political will formation, to the institutionalisation of close channels of communication between high-level economic associations and the political executive, and to the balancing and mediation of rival economic interests in the legislative process. In particular, judicial constitutionalism has usually formed an alternative to constitutions attaching key legitimating functions to collective material rights, secured under collective labour law, and using guarantees for collective rights to integrate corporatist organisations, at different points in the industrial production process, in the legislative apparatus. In such settings, although expansive claims for causality should be resisted, judicial constitutionalism has normally acted to

20 The term 'structure of inclusion' reflects my own construction of a political system. Yet, like more standard concepts of political constitutionalism, it can also be linked to a theoretical background in interwar Germany. For example, Rudolf Smend proposed a related concept of the political system as based in normative processes of integration. See R. Smend, Staatsrechtliche Abhandlungen und andere Aufsätze (Berlin: Duncker und Humblot, 1955) 226. My wider conception of the political system as a 'system of inclusion' is more closely based in the social-systemic theory of Niklas Luhmann, who also obviously knew, and was influenced by, the works of Smend. 
alleviate pressures on the political system caused by its corporatist orientation, and, in different societies, it has gained functional purchase and acceptance because it imposes a normative structure on the political system which dampens pressures created by political corporatism.

After 1945, for example, the first sustained attempts to impose judicial constitutionalism were conducted, with variations, in Japan (1947), Italy (1948), and Western Germany (1949). In these settings, constitutions were established which provided for the institution of powerful courts, authorised to conduct review of primary legislation and to ensure application of international human rights treaties in domestic legislation. These constitutions were all designed to remedy political tendencies linked to interwar authoritarianism, and they did this in a number of quite distinct ways. Notably, however, these constitutions were all specifically intended to loosen the closely interlocked legal, political and economic systems of pre-1945 Japan, Italy and Germany, whose origins were located in the semi-democratic corporatist constitutions consolidated in these societies after 1918, but which had been solidified under fascist or quasifascist governments in the 1920s and 1930s. The judicial constitutional model promoted at this time was obviously marked by US-American experiences with strong independent judicial institutions. However, it was primarily driven by the political-economic policies of the Western allies, notably by the anti-trust emphasis of US-American economic law, which viewed corporatism as a key cause of the rise of extreme political authoritarianism in these societies. ${ }^{21}$ In the 1970s, the new constitutions created in the Iberian transitions, most especially in Spain, ascribed very high authority to judicial actors and very high standing to international human rights norms, applied by national constitutional courts. Notably, moreover, these constitutions promoted a rights-based legal order as a means strategically to eliminate the state-corporatist elements of the political systems established by Salazar and Franco. ${ }^{22}$ In the processes of transformation in Latin America beginning in the 1980s, constitutions were also established that accorded high standing either to newly created constitutional courts or to powerful supreme courts. Albeit to a more limited extent than in earlier European transitions, most constitutions created or rewritten during the liberal reforms in South America made some provision for judicial control of legislation and for domestic enforcement of international human rights. ${ }^{23}$ In addition, these constitutions were generally typified by an explicit anticorporatist bias. Led by the example of Alfonsín in Argentina, whose advisors perceived in corporatism both the cause and the symptom of a deep affliction in

21 See for example L. Hurach-Brand, Antitrust auf Deutsch. Der Einfluß der amerikanischen Alliierten auf das Gesetz gegen Wettbewerbseinschränkungen (GWB) (Tübingen: Mohr, 2004) 216.

22 R. Gunther, Public Policy in a No-Party State. Spanish Planning and Budgeting in the Twilight of the Franquist Era (Berkeley: University of California Press, 1980) 259; J. Martinez-Alier and J. Roca, 'Spain after Franco: From Corporatist Ideology to Corporatist Reality' (1987) 17 International Journal of Political Economy 56, 72.

23 There is a wide spectrum of influence in this respect. Some Latin American states, notably Colombia, Costa Rica and Brazil, obtained powerful courts from the outset of democratisation. Some courts, such as those in Chile and Argentina, were initially relatively weak, although their influence was still enhanced. 
Argentine political structure,${ }^{24}$ most constitutions arising from the South American transitions and transformations strategically weakened constitutional commitments to group rights and political interest balancing. Following the political upheavals in post-1989 Eastern Europe, then, most new constitutions in former communist states provided for strong courts with extensive power to review primary laws, which promoted a deep interpenetration between domestic law and international human rights law. In this setting, self-evidently, the rejection of corporatism was less ideologically explicit than in other transitions, as, up to 1989, Eastern European states had projected themselves as states that had effectively resolved class conflicts, so that corporatist equilibration of divergent economic interests was not required. However, the pre-1989 public economies of many Eastern European states often had quasi-corporatist features, and, like polities with corporatist constitutions, they were pervasively marked by deep intersection between the state executive and holders of semi-private or local, sectoral authority. ${ }^{25}$ Accordingly, the new constitutions established after 1989 generally acted to reduce the interpenetration between the political system and private or quasi-corporate organisations. ${ }^{26}$ In Sub-Saharan Africa, ultimately, the democratic reforms beginning in the early 1990s, driven partly by popular movements and partly by economic adjustment policies dictated by the International Monetary Fund, also usually created constitutions that raised the standing of courts and promoted singular rights through society. As in other contexts, the new constitutions in Africa were normally, though with salient exceptions, marked by an anti-corporatist orientation. ${ }^{27}$ Notably, these constitutions were widely conceived as alternatives to corporatist constitutions established in most African countries through the process of decolonisation, which integrated economic organisations in the state periphery and tied the political system to powerful players and organised interests throughout society. ${ }^{28}$ In particular, the reformist constitutions in Africa were intended to reduce the direct impact of private interests on state structure, and to construct the legitimacy of the state, not through satisfaction of embedded sectoral interests, but in general inclusionary norms, condensed into judicially applied rights. ${ }^{29}$

24 See C. Santiago Nino, Radical Evil on Trial (New Haven, CT: Yale University Press, 1996) 132.

25 See J. P. Willerton, Patronage and Politics in the USSR (Cambridge: CUP, 1992) 227.

26 See my analysis, C. Thornhill, A Sociology of Constitutions: Constitutions and State Legitimacy in Historical-Sociological Perspective (Cambridge: CUP, 2011) ch 5. Note, however, that some Eastern European societies evolved quasi-corporatist patterns of economic administration after 1989. See H. Balzer, 'Managed Pluralism: Vladimir Putin's Emerging Regime' (2003) 19 Post-Soviet Affairs 189, 197.

27 The main exception is South Africa, where a semi-corporate system was established after the end of apartheid. See A. Habib, 'From Pluralism to Corporatism: South Africa's Labour Relations in Transition' (1997) 24 Politikon: South African Journal of Political Studies 57, 62.

28 For case studies see L. N. Trachtman, 'The Labor Movement of Ghana: A Study in Political Unionism' (1962) 10 Economic Development and Cultural Change 183, 185; J. R. Heilbrunn, 'Social Origins of National Conferences in Benin and Togo' (1993) 31 Journal of Modern African Studies 277, 284.

29 One account argues expressly that constitution making is a technique for state construction in Africa. See P. Ogaba Agbese and G. Klay Kieh, 'Introduction: Democratizing States and State Reconstruction in Africa' in P. Ogaba Agbese and G. Klay Kieh Jr (eds), Reconstituting the State in Africa (Basingstoke: Palgrave, 2007) 3, 18. 
Almost uniformly, in short, the rise of judicial constitutionalism is related to the demise of corporatist constitutionalism. In each wave of constitution writing in which the judicial form of contemporary constitutionalism was cemented, the evolution of this form was partly determined by a historical background in which state corporatism had been the dominant legal-political structure. Often, in fact, the model of judicial constitutionalism was constructed precisely because it served to remedy problems of political structure that had been induced by the internalisation of private corporations in the political system which is promoted by state-corporatist constitutionalism. In order fully to comprehend the new judicial-constitutional model, therefore, we need to evaluate the ways in which corporatist constitutionalism impacted on the political structure of different societies, and we need to observe how the expansion of judicial power was related to this. Indeed, the current prevalence of judicial constitutionalism can be partly explained through analysis of certain quite specific structural features and consequences of political corporatism.

Striking in corporatist constitutionalism, first, is the fact that it was usually developed as a constitutional model that was intended to help political institutions to respond to rapidly escalating societal demands for law, to sharply increasing social expectations of legal/political inclusion, and to a deepening penetration and densification of the political system as a whole. In most societies, corporatist constitutionalism emerged as an immediate result of the transition to mass democracy, through which the sectors of society that assumed pressing relevance for the political system rapidly increased in number, the reach of the political system into society was intensified, and the mass of societal actors demanding recognition in law-making expanded beyond precedent. This occurred, typically, after World War I in Europe, between the 1930s and the 1950s in Latin America, and in the course of decolonisation in Southern Africa. At a general level, corporatist constitutionalism reflected this transformation of the political system because it was promoted as a legal form to ensure the full inclusion of all social interests in the state, and, to some degree, it attempted to construct all social groups and organisations as constituents of public law. Corporatism was originally conceived as a public-legal order that generated legitimacy for newly established democratic states by ensuring that the institutions of the state were founded in the will of all sectors of society, and that all interests in society, both material and political, could be mediated and publicly enacted through the ramified organisational apparatus of the state. In some respects, state-corporatist constitutionalism deliberately echoed the Marxist critique of the liberal constitutional polity as a thin ideological artifice. ${ }^{30}$ In early examples of democratic corporatism, especially in post-1918

30 For a classical expression of democratically inclusive corporatism see H. Sinzheimer, Ein Arbeitstarifgesetz. Die Idee der sozialen Selbstbestimmung im Recht (Munich: Duncker \& Humblot, 1916) 35. For a theoretical refined account of a state with a corporate constitution, founded through the unification of different social organisations, see H. Heller, Die Souveränität. Ein Beitrag zur Theorie des Staats- und Völkerrechts in H. Heller, Gesammelte Schriften, edited by M. Drath, F. Borinski, and G. Niemeyer (Leiden: Sijthoff, 1971) vol II, 31, 96-97. Even authoritarian, or fascist, corporatism echoes the Marxist critique of liberal legalism. See for example G. Gentile, Origini e dottrina del fascismo (Rome: Libreria del littorio, 1929) 49 
Europe, the claim was widespread that the state could only acquire and preserve legitimacy if it unified the full plurality of private-economic interests in society, and if it converted these interests into a distinctively public/political constitutional will, able to steer and produce authoritative legislation for society both in its strictly political and in its economic dimensions. ${ }^{31}$ In particular, most corporatist constitutions aimed to integrate societal organisations in the state by allocating group rights to collective actors and organisations, and by tying the legitimacy of the state to its capacity to satisfy collective rights claims, expressed through corporate bodies. ${ }^{32}$ At the core of corporate constitutionalism, thus, is the profoundly inclusionary assumption that a political system can only fully authorise legislation if it binds collective associations into its own structure and if it establishes cross-class, inter-sectoral agreements, relating to all spheres of social interaction, which are then represented and enforced through the constitutional order of the state itself. The legitimacy of the corporatist constitution embodies an externalist concept of legitimacy, in which the original source of legitimacy is positioned outside the political system, and legitimacy must be constantly produced and demonstrated for each and every act of legislation through the objective mediation, or at least pacification, of rival external interests, often extremely conflictual in character.

Equally notable, second, is the fact that, by most accepted definitions, corporatist constitutionalism is a highly political pattern of constitutional organisation. Corporatist constitutionalism can be characterised as political because it marks out a large number of interactions and organisations in society as relevant for the political system and as constitutively implicated in the formation of the will that confers legitimacy on laws. In particular, such constitutionalism defines labour law as a primary medium of political integration, and it attempts to incorporate society in the political system by using collective labour contracts to establish cross-class collaboration in economic legislation: labour law thus becomes a formative component of the constitutional order. ${ }^{33}$ Corporatist constitutionalism can also be seen as political because it makes the legitimacy of the state contingent on clearly dictated policies of economic integration, and it insists that the validity of law depends on its efficacy in fulfilling broad programmatic political-economic objectives. ${ }^{34}$ Corporatist constitutionalism

31 The classic example of this is the Weimar Constitution, and its provisions for council-based democracy as a source of law, formalised in Art 165.

32 For example, the constitution of Salazar's Estado Novo of 1933 claimed to establish a state based in an 'equilibrium' between the active demands of labour and capital (Art 31). In consequence, the constitution committed the state to promote a 'national corporate economy'; to limit unrestricted economic competition (Art 34); and to police relations of property, capital and labour so that their 'social function' was preserved (Art 35). Analogously, in Perón's constitution of 1949 in Argentina, Art 37 guaranteed a long catalogue of social rights. Art 38 declared that 'private property has a social function' and is subject to interests of common good, and it authorised the state to intervene in economic practices in order to stimulate development.

33 In authoritarian corporatism, "the "collective labour contract" was defined as an "act of public law", F. Guidotti, Il contratto collettivo di lavoro nel diritto corporativo (Rome: Maglione, 1935) 86. More democratic corporatist systems also clearly opposed the separation of labour law from constitutional law.

34 Accordingly, most corporatism has a strong developmentalist bias. For a study of the legal implications of developmentalism, see R. Teti, Codice Civile e regime fascista. Sull'unificazione del diritto privato (Milan: Giuffrè, 1990) 141. 
has a strong political substance, further, because it directly politicises conflicts in society, the resolution or at least palliation of which it construes as the precondition of the state's legitimacy. As a result, it encourages potent social groups to vie for resources allocated by departments of state, and it offers these groups immediate access to political goods. In consequence, corporatist constitutionalism creates a situation in which rival organised groups in society are likely to position themselves close to institutions of state, and even to observe public offices as instruments to secure private societal advantages. Central to corporatist constitutionalism, in short, is a deep and intense politicisation of the political system and a deep and intense politicisation of society as a whole.

Of further significance, third, is the fact that few examples of democratic corporatist constitutionalism survived for any length of time. Most corporateconstitutionalist democracies were almost immediately supplanted by political systems that, although preserving certain corporatist elements, abandoned the assumption that the state acquired legitimacy through the inclusionary process of democratic conflict mediation. Instead of this, corporatist constitutions were usually superseded by, or in fact rapidly faded into, constitutions in which the political system established its social foundations through anti-democratic, exclusionary corporatist procedures: ${ }^{35}$ that is, by co-opting a small number of powerful private actors into the political system, and by distributing privileges amongst select private groups (either financial or ethnic), which were then expected, in return for continual remuneration, influence and reward, to provide a substructure of support for the political system across society. With a few rare exceptions, corporatist constitutions imposed unmanageable burdens of conflict mediation on states. In most states, this problem of systemic/inclusionary overstretch had the result that legislative power was transferred to the private organisations which they had allowed to gain access to public offices, and, ultimately, authority was ceded to particular private actors which, owing to its corporatist design, had assumed entrenched positions within the political system. ${ }^{36}$ As a result of this, most states based in corporatist constitutions were extremely susceptible, either catastrophically or cyclically, to structural collapse, through which, in many cases, they ultimately lost their public or categorically

35 In making this claim, I suggest that a political system always presupposes some generalised support amongst different groups in society. Authoritarian political systems, however, tend to construct support very selectively, usually by giving direct expression to the interests of a small group of dominant elites. See analysis in different cases in C. L. Arceneux, Bounded Missions. Military Regimes and Democratization in the Southern Cone and Brazil (University Park, PA: Pennsylvania State University Press, 2001) 56; G. O'Donnell, 'Corporatism and the Question of the State' in J. M. Malloy (ed), Authoritarianism and Corporatism in Latin America (Pittsburgh, PA: University of Pittsburgh Press, 1977) 47, 48; S. G. C. Leonardo Silva, Relações coletivas de trabalho: configurações institucionais no Brasil dos anos 1990 (São Paulo: LTr, 2008) 200, 202; T. M. Shaw, 'Beyond Neo-Colonialism: Varieties of Corporatism in Africa' (1982) 20 Journal of Modern African Studies 239, 256.

36 For different examples of the corporatist hollowing of the state, see E. Zimmermann and T. Saalfeld, 'Economic and Political Reactions to The World Economic Crisis in Six European Countries' (1988) 32 International Studies Quarterly 305; 328; S. Borner and M. Kobler, 'Strength and Commitment of the State: It Takes Two to Tango: A Case Study of Economic Reforms of Argentina in the 1990s' (2002) 110 Public Choice 327, 340. 
political distinction as states. In most cases, the experiment in corporatist constitutionalism resulted in the overthrow of democratic governments and the resultant emergence of highly privatistic, internally fragmented governmental regimes, obtaining compliance in society through a mixture of semi-private economic bargains and extremely violent political coercion. These regimes, normally based in fascist or one-party dictatorial executives, were typically defined by the growth of patronage, corruption, and prebendalism, by the volatile hyperpoliticisation of public offices, and even, in extreme cases, by the transformation of state offices and other resources into spoils for privileged groups. ${ }^{37}$ State institutions formed under corporatist constitutions have almost invariably proved incapable of withstanding the politicisation of society to which corporatism inevitably gives rise. Corporatist constitutionalism promoted a high level of politicisation, or even hyperpoliticisation. ${ }^{38}$ But it almost invariably created a political system defined by high levels of inner privatism: that is, by the fact that external actors could take advantage of the political system's weakness to assume direct personal influence on public offices and policies. $^{39}$

\section{JUDICIAL CONSTITUTIONALISM AS A PRECONDITION OF POLITICS}

As mentioned, this background of corporatist constitutionalism has particular relevance for analysis of judicial constitutionalism. In fact, judicial constitutionalism has certain characteristics that have served, in many settings, to counteract, and even specifically to obviate, the pathologically privatistic impact of corporatism on society's political structure.

Crucially, for example, one defining characteristic of constitutions with a strong judicial emphasis is that, in linking political legitimacy to internationally defined, and judicially applied human rights norms, they enable states to acquire and presuppose some element of legitimacy for legislation, which these states are not expected to create for themselves. Under the classical model of constitutionalism, states were required to construct legitimacy for law by politicising conflicts and securing collective agreements between concretely existing groups in society at large. In most cases, as democracies approached a condition of full enfranchisement, this exposed states to very extensive demands for

37 On fascism as political privatism see D. Rebentisch, Führerstaat und Verwaltung im Zweiten Weltkrieg. Verfassungsentwicklung und Verwaltungspolitik 1939-1945 (Stuttgart: Franz Steiner, 1989) 283; G. Schulz, Die Anfänge des totalitären Maßnahmenstaates (Frankfurt am Main: Ullstein, 1974) 294.

38 Hyperpoliticisation is defined here as a process in which the political system is opened to multiple conflictual processes in society, such that it forfeits its robustness in face of these conflicts, enabling prominent actors in the dynamics of social conflict to take control of formal offices of state.

39 On the connection between hyperpoliticisation and corporatism in different settings see J. M. Malloy, 'Authoritarianism and Corporatism: The Case of Bolivia' in Malloy (ed), n 35 above, 457, 478; P. Gerchunoff, 'Peronist Economic Policies, 1946-55' in G. di Tella and R. Dornbusch (eds), The Political Economy of Argentina, 1946-83 (Pittsburgh, PA: University of Pittsburgh Press, 1989) 59, 59; A. R. Zolberg, 'The Structure of Political Conflict in the New States of Tropical Africa’ (1968) 62 American Political Science Review 70, 73. 
legitimacy, and different organs within these states were required to mediate deep-lying conflicts to support and legitimate the increasingly expanding mass of legislation which they were expected to produce. In most cases, as discussed, states attempted to meet rising demands for law and legitimacy by adopting corporatist systems of public law, based in the integrative force of collective material rights, but they were not able to withstand the pressures arising from the politicisation of society which corporatism induced. The rise of judicial constitutionalism, however, has often simplified the procedures through which governments can react to demands for law and legitimacy in mass democracies. In particular, judicial constitutionalism has proportioned the legitimacy of government actions to formally generalised standards of legitimacy, enabling them to define and to reproduce their legitimacy in categories extracted from, and pre-stabilised within, international human rights law. This has often had the outcome that states have been able to conserve legitimacy in abstract, internal legal principles, which they supply to accompany legislation, so that they are able to manifest normative support for laws without extreme volatility, and they can produce law while insulating themselves against intense objective societal conflicts. ${ }^{40}$ As the norms of international law first permeated national law, notably, states were able to pass laws using pre-established principles of legitimacy, and they were relieved of the requirement endlessly to integrate social organisations, endlessly to mediate social conflicts, and endlessly to manufacture all the legitimacy that they needed to support all acts of legislation. ${ }^{41}$ To a limited degree, therefore, states have evolved the capacity, through judicial constitutionalism, to depoliticise their own legitimacy.

40 Tellingly, in a number of post-corporatist transitions, international human rights norms, applied by powerful domestic courts, have formed the premise for a system of pacts between different stakeholders in the transition. The ability of these stakeholders to accept compliance with international law as a standard of democracy has served to produce sufficient consensus for transition, insulating the transition against otherwise unmanageable divergence between different parties. One obvious example of this is post-1983 Argentina, and a slightly less self-evident example is post-1989 Chile. The paradigmatic example, however, is post-1978 Spain, in which a prominent commitment to judicial enforcement of international norms provided a normative constitutional superstructure, beneath which a pacted transition to democracy could be conducted. See A. Stepan and J. Linz, 'The paradigmatic case of Reforma Pactada-Ruptura Pactada: Spain' in J. Linz and A. Stepan (eds), Problems of Democratic Transition and Consolidation: Southern Europe, South America and Post-Communist Europe (Baltimore, MD: Johns Hopkins University Press, 1996) 87. The South African transition does not immediately fit the model of a post-corporatist transition. But similar claims could be made about the depoliticising role assumed by judicially enforced rights in South Africa after 1989. See n 52 below.

41 In some famous cases in post-corporatist polities, courts simply enunciated a categorical normative grammar for all society. The most striking example of this is the Lüth ruling of German Constitutional Court in 1958. The Lüth ruling was not expressly based in international law, but it clearly reflected the openness of West German law to international law declared in Grundgesetz Arts 24, 25, 26 and 100(2). Notably, it cited from the French Declaration of the Rights of Man in 1789 to define the right to free expression of opinion as 'the most immediate expression of human personality': West German Constitutional Court 1 400/51 (Lüth) (15.1.1958) 42. For comment see T. Henne, 'Von O auf Lüth in $6 \frac{1}{2}$ Jahren: Zu den prägenden Faktoren der Grundsatzentscheidung' in T. Henne and A. Riedlinger (eds), Das Lüth-Urteil aus (rechts)-historischer Sicht. Die Konflikte um Veit Harlen und die Grundrechtsjudikatur des Bundesverfassungsgerichts (Berlin: Berliner Wissenschaftsverlag, 2005) 197. 
In this respect, the rise of judicial constitutionalism has had the common outcome that it has reduced the reliance of the political system on principles or bargains articulated outside its own structure, and it has placed limits on the externalism of the political system's legitimacy. Owing to the growing ability of national political systems to refer to international rights norms as principles to legitimate legislation, the source of legitimacy for single laws has been re-located from a position in society outside the political system to a position inside the political system. ${ }^{42}$ This has meant that laws could be generated and legitimated in internal, relatively apolitical style; it has meant that the principles used to confer legitimacy on laws could be abstracted inner-systemically, without a manifest or potentially unsettling external reference, so that legitimacy for legislation can in part be produced from norms always stored inside the political system. In the contemporary model of judicial constitutionalism, therefore, a legal/political system has begun to emerge which - to some degree - is able to create, to legitimise laws from within itself, and which brings validity to laws through reference to already existing, internally conserved, norms, at least partly derived from the international domain. In contemporary judicial constitutionalism, first, the founding laws of the constitutional polity are not created solely by a primary act of political volition. ${ }^{43}$ The radical exercise of a constituent power is typically absent in judicial constitutionalism, and constitutional laws normally come into being as they are shaped by international agreements, usually applied and watched over by courts, and usually centred in formal rights. In this respect, the law creates law; law internally authorises law, and principles of international law, usually drawn from human rights, distil the Grundnorm for the constitutional polity. In contemporary judicial constitutionalism, second, the laws of day-to-day life do not solely draw their authority from reference to external exigencies. ${ }^{44}$ Laws are partly pre-formed by already existing norms, and they are intensely influenced by the actions of

42 There are many examples of rulings in post-corporatist states in which courts have applied international human rights norms to stabilise labour conflicts, and ultimately to locate such conflicts outside the state. Notable examples are found in post-1948 Italy, post-1949 West Germany, post-1975 Spain, post-1983 Argentina, post-1984/85 Brazil, and post-1992 Ghana. As a particularly illuminating examples see West German Constitutional Court, 4, 96 (Hutfabrikant) (18.11.1954); Argentine Supreme Court, Cocchia, Jorge Daniel (Sindicato de Encargados Apuntadores Marítimos) c/ Estado Nacional y otro s/ acción de amparo. FALLOS: 316:2624, C. 802. XXIV.

43 In classical examples in different settings - for example, West Germany in Europe, Argentina in Latin America, and Ghana in Africa - new constitutions extracted only part of their legitimacy from founding acts of a constituent power. Their legitimacy was also explained, to an at least equal degree, as deriving from the enactment, and subsequent judicial enforcement, of international human rights law.

44 To illustrate this, we can think of a large number of examples. In extreme cases, states converting to a judicial-constitutional model have often introduced laws solely to enact human-rights conventions, often at the prompting of courts. Many examples of this can easily be found in post-1989 transitions in Eastern Europe, notably Hungary and Poland. In less extreme cases, states converting to judicial constitutionalism allow courts to double-check the legitimacy of laws, and to supplement the authority of laws in light of human-rights standards. This has particular importance when laws are introduced in the face of deep-rooted social opposition; laws acquire additional, abstracted authority through this process. Striking examples of this are currently observable in Chile, in which judicial power has been substantially augmented in the last few years, especially since 2005. In one very recent case, the Chilean government introduced 
courts, situated both in domestic and in cross-national settings, which usually assert international human rights as the ultimate basis for legislation. In short, in the political system defined by judicial constitutionalism, law is its own origin and author; law is created not outside but, recursively, within the political system, and the political system maintains its legitimacy through reference to laws which it already contains.

For both these reasons, significantly, judicial constitutionalism has served in most societies to counteract both the convergence of social conflict around the political system and the unsettling intersection between public offices and private organisations, which were typically effected by corporatist constitutional arrangements. In most cases, judicial constitutionalism has greatly raised the integrity of the state - as a distinct and differentiated political system in relation to private actors. ${ }^{45}$ This is particularly linked to the fact that judicial constitutionalism strengthens the role of formal human rights norms in the legislative process, so that laws are increasingly considered valid insofar as they are consonant with pre-constructed rights-based norms and applied to single persons in society as holders of general rights. In most cases, the judicial model of constitutionalism replaced an order of state founded in group-based patterns of rights holding, and it proposed internationally constructed rights as an alternative to associational rights as the primary mechanism through which states seek to obtain legitimacy. ${ }^{46}$ In most cases, accordingly, the shift in emphasis from collective rights to single rights as principles of constitutional legitimacy meant that the directional apparatus of the state as a whole was stripped away from densely interlinked organisations, such as cartels and trade

reform laws placing restrictions on the autonomy of institutions of higher education, touching a particularly sensitive nerve in a society still marked by the climate of social privatisation created by Pinochet. Notably, after it was subject to legal challenge, this law was approved by the Constitutional Court, which cited international treaties to support its ruling. See Chilean Constitutional Court, Rol 2787 (1/4/2015). Quite generally, in states marked by strong courts, compliance with international standards inevitably forms one part of the legitimacy of each law, and international norms are always co-implied in legislation.

45 Some clarification is required here of my understanding of 'the state'. Of course, sociological literature usually rejects static or socially abstracted constructions of the state, and the most important sociological reflections on the state are designed to unearth the processes of coercion and domination which underlie the power of states. This endeavour forms the backbone of political sociology, from Karl Marx, to Max Weber, to Antonio Gramsci, to Charles Tilly, to Pierre Bourdieu, and these perspectives have entered the bloodstream of common intellectual discourse. I do not wish to propose a monolithic theory of the state, and I do not wish to suggest, in seeming antipathy to the basic tenets of political-sociological inquiry, that the state is an entirely abstract set of institutions. Nonetheless, underpinning my argument is the claim that a state is defined as such by its public/political quality. However it is constructed, a state obtains its quality as a state by the fact that it is not fully transparent to a given set of private societal interests; that it has a position of partial differentiation in society as a whole; that, in certain circumstances, it can act against or in indifference towards powerful actors in the society in which it is located; and, above all, that it can produce legislation without reliance on, or co-option of, external parties. Central to this concept of the state is the principle that a state can produce law positively and from within itself. For further analysis of this construction of the state and for similar perspectives, see my discussion in C. Thornhill, 'Fascism and European State Formation: The Crisis of Constituent Power' in Rask Madsen and Thornhill (eds), n 1 above, 29,30 . On this basis, the state stands at the centre of a system of legal inclusion in a national society.

46 See notes 34 and 35 above. 
unions, which had utilised the integrational force of group rights to infiltrate the legislative process. Typically, this shift away from group rights has reduced tendencies towards societalisation, patrimonialism, and resultant re-privatisation within the state. ${ }^{47}$ In each respect, judicial constitutionalism has provided internal normative support for political systems which has enabled them to legislate for their societies at a relatively high level of differentiation and positive autonomy.

These features of judicial constitutionalism expose us to a substantial paradox. On one hand, clearly, judicial constitutionalism lacks the features commonly associated with classical or political constitutionalism. As explained, judicial constitutionalism evidently dampens the deep-lying cycles of politicisation caused by corporatist constitutionalism, and it confers a static formal grammar on processes of legitimisation which are perceived, in classical terms, to form the most intensely political dimensions of constitutional practice. Clearly, the judicial constitution is not focused on the expression of a primary political will, and it restricts the degree to which political systems can explain their legitimacy, in Schmitt's sense, as the result of concrete, constituent or even external acts of will formation. ${ }^{48}$ In addition, judicial constitutionalism does not extend the sphere of politically constitutive acts very deeply into society, and it has the distinctive feature that laws can be authorised and legitimised within the political system, without the need to satisfy extensive external expectations of societal conflict mediation.

On the other hand, however, judicial constitutionalism has generally promoted the formation of states that are more publicly - or, in the strict sense, politically - constituted than states which are constitutionally opened to high expectations of political integration. In particular, it has led to the construction of states which are more consistently able to define themselves in distinction from specific groups and specific interests located outside the political system than those which they have replaced. As soon as we renounce more conventional, conflictual approaches to society's political substance, in fact, it appears that judicial constitutionalism possesses a quite distinctive political quality, and it effectively promotes the formation of a differentiated political system, capable of performing reliable processes of political inclusion.

Observed from a more sociological perspective, in sum, the judicial constitution has usually proved relatively successful in preserving systemic/inclusionary functions across society, and - above all - it has played an important role in allowing different societies to abstract and preserve a relatively autonomous political structure. A defining part of this process is that in judicial constitutionalism the norms that legitimate the law enter the political system from the

47 The classic example of this is the Argentine transition in the 1980s under Alfonsin, who used international human rights law as a platform for detaching the state from corporate organisations. Note, as background, the typology of corporatism in P. Kjaer, 'Toward a Sociology of Intermediary Institutions: The Role of Law in Corporatism, Neo-Corporatism, and Governance' in Rask Madsen and Thornhill (eds), n 1 above, 117. The shift from state corporatism to societal corporatism described by Kjaer usually coincided with the creation of national constitutions with a judicial accent, partly based in international human rights law.

48 See C. Schmitt, Politische Theologie (Berlin: Duncker und Humblot, 1922) 11. 
international domain (usually international human rights law), and, owing to their external, relatively abstracted source, they allow the political system to adapt to otherwise unsettling demands for legitimacy. Through this process, international law becomes part of the domestic political structure; in fact, seen sociologically, international law forms a precondition for the basic solidification of a political domain in society. In its sociological consequences judicial constitutionalism can be seen as very political, and principles of international law usually evident in judicial constitutionalism often play a key role in the formation of a national political system. With judicial constitutionalism, a constitutional system has evolved in contemporary society which is relatively adept at stabilising inclusionary political structures. The fact that states have developed a constitutional order through which they can presuppose a degree of legitimacy based in judicially applied international norms, which they can derive from a relatively static, depoliticised source, has widely assumed vital significance in the stabilisation, or de-privatisation of the modern political system as a distinct inclusionary domain. The constitutional form that is now commonly seen as negating political constitutionalism in fact developed as a reaction to an endemic crisis of the political - to a deep and debilitating loss of political structure in different national societies. As discussed, much analysis associates the political constitution with a constitution that draws legitimacy from the direct historical expression of a national will. ${ }^{49}$ In fact, however, most societies only acquired a distinctly political structure as they detached legitimacy from national constituent agency and as they tied legitimacy instead to transnational patterns of judicial norm construction. As a point of general principle, and with rare exceptions, it was only through the self-depoliticisation of the political system which occurred through the rise of judicial constitutionalism and the attendant absorption of national states in a transnational system of rights that it became possible for national societies to construct and preserve their political functions as a differentiated system of societal exchange and inclusion. In many cases, the judicial dimension of contemporary constitutionalism has made it possible for states to preserve a basic political structure, even when forced to address and mediate between the interests of groups articulating interests at an extreme level of political intensity. ${ }^{50}$

49 For the origin of this view see C. Schmitt, Verfassungslehre (Berlin: Duncker und Humblot 1928).

50 The classic example of this is post-apartheid South Africa. In this setting, the transitional state was forced to refract deep contests both between ethnic opponents and between opponents in the production process; notably, trade unions had been radically politicised in the later apartheid era, and trade-union politics were often tied to racial politics. See E. C. Webster, 'The Politics of Economic Reform: Trade Unions and Democratization in South Africa' (2007) 16 Journal of Contemporary African Studies 39, 53. However, the transition was presided over by a powerful judiciary, especially by the Constitutional Court established in the interim constitution of 1993. This court was authorised to ensure that certain norms were extracted as ground-rules for the entire transition, thus insulating the emergent democratic state against unmanageable politicisation. See H. Klug, Constituting Democracy. Law, Globalism and South Africa's Political Reconstruction (Cambridge: CUP, 2000) 1. The fact that the court was able to exclude certain prior norms, notably human rights principles, from social contestation secured the process against the dynamics which it unleashed, and it helped to preserve a residual political structure above these conflicts. Hungary is also notable in this regard. In 1993, the Hungarian Supreme Court stated that 'generally recognized rules of international law' need to be seen 'without any (additional) transformation' as 'part of Hungarian law.' This ruling declared participation 
Overall, the assessment of judicial constitutionalism is misdirected if it contrasts judicial constitutionalism with political constitutionalism. Usually, judicial constitutionalism developed as an alternative, not to political, but to privatistic constitutionalism, and it is in this relation that its implications can be most realistically assessed. Seen in this perspective, judicial constitutionalism has normally proved, not an anti-political legal form, but rather a precondition for the emergence and perpetuation of a distinct political domain in society.

\section{THE SPACE OF POLITICAL CONSTITUTIONALISM}

On this basis, it is tempting simply to dismiss more classical conceptions of political constitutionalism and more classical concepts of the political quite broadly. On the account offered here, theories that adopt a classical - that is, a conflictual or voluntaristic - approach to the politics of constitutionalism remain attached to rather simplified understandings of social formation, and to excessively universalised notions of political substance. Despite this, nonetheless, it still appears over-hasty to suggest that the (classically defined) political content of constitutionalism has entirely disappeared. In fact, it is currently possible to discern important constitutional developments, across a range of national settings, in which judicial constitutionalism, centred in particular on the horizontal checking of national laws by internationally extracted norms, has begun to promote new patterns of clearly political constitution making, and it has allowed a variety of atypical processes of political structure building to emerge. In recent years, international law, especially in the form of international human rights norms, has been applied by courts in some societies as a distinctive source of inclusionary structure, and it has been used to produce constitutional forms more commonly associated with highly volitional patterns of norm construction: international law has often fused with national political agency to construct a sui-generis transnational constitution-making will. In some cases, the judicial absorption of international law in domestic law has even led to a reconfiguring of some classical concepts of political constitutionalism, notably constituent power, and, in different societies, it has permitted political institutions to extract legitimacy from constituent power in a distinctively controlled, insulated fashion, reducing the risk of their destabilisation by the enactment of such power. In this process, international law, conventionally construed as circumscribing national political voluntarism, ${ }^{51}$ has entered domestic societies in a number of contingent ways, and it circulates widely through national societies as a premise for political will formation, political institution building, and political inclusion more generally. Indeed, it appears that in some societies leading political actors have learned specifically to adapt aspects of judicial constitutionalism and to internalise international norms as

in the 'international community of people' a 'constitutional imperative for inner-state law', G. Brunner and L. Sólyom, Verfassungsgerichtsbarkeit in Ungarn. Analysen und Entscheidungssammlung 1990-1993 (Baden-Baden: Nomos, 1995) 524-525. Through this, the court became the primary bearer of constituent power, and it used this power independently to determine the basis for legislation.

51 See n 19 above. 
instruments for managing the dynamics of political will construction, and for fostering patterns of political constitutionalism that are sensitive and specifically adapted to instabilities in the inclusionary structure of society. Accordingly, such actors utilise elements of judicial constitutionalism to securitise historically precarious processes of political institution building, and to create political constitutions on a hybridised political/judicial foundation. Many societies have thus begun, however incompletely, to elaborate a publicly inclusionary structure by incorporating international judicial norms within more conventional acts of political foundation, and they establish political constitutions through an adaptive fusion of national and transnational legal principles. Where this occurs, international law, refracted through judicial constitutionalism, is sociologically transformed into a source of controlled political agency, expanding a sustainable political structure across national societies. Overall, therefore, political constitutionalism is now in the process of re-emerging, and new composites of judicial and political constitutionalism are beginning to become visible. In such cases, however, the generically political dimension of constitutionalism cannot be captured if it is linked to simple processes of popular volition, conflict mediation, or deliberation. The political dimension of such hybrid judicial/political constitutionalism lies in the fact that, especially in settings in which this had historically proved tortuous and precarious, it makes it possible for a society to sustain a basic structure of inclusion, and it forms a remedy to persistent histories of structural fragmentation. In national contexts marked by endemic dissolution of political institutions, in fact, the hybrid fusion of judicial and political constitutionalism appears to be evolving as a reliable source of political inclusion.

Examples, albeit very divergent, of the emergence of a hybrid model of judicial/political constitutionalism can be seen in a number of recent processes of transitional or transformative constitution writing:

\section{Russia}

Russia might seem (and in fact is) a rather unlikely case to illuminate patterns of contemporary constitution making. At an executive level, Russia possesses a partly authoritarian political system, which, notable advances in the last ten or so years notwithstanding, can only be placed in the margins of common categories of constitutionalism. ${ }^{52}$ Moreover, the history of Russian constitutionalism since

52 I am unconvinced by the common classification of contemporary Russia as a simply authoritarian regime. The dominant-party model is a more accurate paradigm for defining the Russian political system. See on this S. Levitsky and L. Way, 'The Rise of Competitive Authoritarianism' (2002) 13 Journal of Democracy 51, 53; V. Gel'man, 'Party Politics in Russia: From Competition to Hierarchy' (2008) 60 Europe-Asia Studies 913, 915. Usually, a dominant party might have some semi-authoritarian features, and it might partly control access to political offices or distribute political influence to preserve its monopoly of power. On the more authoritarian aspects of rule by dominant party, see O. John Reuter, 'The Politics of Dominant Party: United Russia and Russia's Governors' (2010) 62 Europe-Asia Studies 293, 295. But it is not necessarily the case that a dominant-party system is exclusively authoritarian, and a political system of this kind can also, as explained here, contain very progressive dimensions. In general, discussion about the Russian legal and political system remains lamentably ill-informed and prejudiced, a fact at least partly 
the 1980s has been punctuated by occasional placing of restrictions on the judicial branch, and by at times flagrant antipathy to the constraints imposed on national government by international human rights instruments. Russia, in short, does not readily lend itself to analysis of judicial constitutionalism.

Despite this, in important respects, the Russian polity clearly belongs in the judicial-constitutional fold. ${ }^{53}$ In fact, it exemplifies a distinctively hybridised political reconstruction of judicial constitutionalism, in which transnational norms, mediated through national courts, have been used to stabilise a very distinctive political constitution. Significantly, for example, the post-transitional constitution of 1993 created a strong Constitutional Court with extensive powers of judicial review, and it accorded high standing to international law, including international human rights instruments. In its early years under Zorkin, the Russian Constitutional Court often acted audaciously in fulfilment of its duties concerning review of primary laws, and it clearly reflected the wider trend towards 'courtocracy' in the democracies that first emerged in post-1989 Eastern Europe ${ }^{54}$ Although allegedly more subdued since its dissolution by Yeltsin and its eventual re-foundation in $1995,{ }^{55}$ the court has maintained a fluctuating, yet not unimpressive, record in its attempts to impose standards of accountability on Russian government. This is demonstrated by the court's reception of international human rights law, which it uses as a standard to test anti-government appeals and litigation, ${ }^{56}$ and at times to strike down political legislation. ${ }^{57}$ Notably, further, since its accession to the ECHR in 1998, Russia has enjoyed a fractious and often conflictual relation with the European Court of Human Rights (ECtHR). However, the ECHR has acquired a very important position in Russian public law, and citations from the Strasbourg court are increasingly common. Although in Konstantin Markin $\mathrm{v}$ Russia ${ }^{58}$, the ECtHR

responsible for the yet more lamentable policies of Western governments towards Russia during its long trajectory of reform and institutional consolidation.

53 Data in this paragraph was compiled by Dr Maria Smirnova, Research Associate in Russian Law at the University of Manchester. It was extracted from the legal database: ConsultantPlus at www.consultant.ru (last accessed 13 November 2015). Maria's work on Russian law has been of immense value. She also read and commented on this paragraph. All usual caveats of course apply.

54 K. Lane Scheppele, 'Constitutional Negotiations. Political Contexts of Judicial Activism in Post-Soviet Europe' (2003) 18 International Sociology 219, 222.

55 See sharply divergent views on this in A. Trochev, Judging Russia. Constitutional Court in Russian Politics 1990-2006 (Cambridge: CUP, 2008) 185; A. Mazmanyan, 'Judicialization of Politics: The Post-Soviet Way' (2015) 13 International Constitutional Law 200, 214.

56 See for example the Russian Constitutional Court Decision on merits (Postanovlenie) No 2-P of 17 February 2015. In this case, certain provisions of the Federal Law on the Prosecutor's Office regarding the agency's power to inspect non-government organisations and suspend their activities without a court decision were held unconstitutional. The application was made by a group of NGOs.

57 One argument implies that the Russian courts have moments of bravado in reviewing administrative acts, but lack confidence in reviewing acts in the political sphere (see Mazmanyan, n 55 above). However, the Russian Constitutional Court has recently declared a number of important laws unconstitutional, including laws in core areas of public policy: taxation and health. The Constitutional Court thus shows a relatively high level of judicial activism. For a recent ruling striking down taxation laws see Russian Constitutional Court Ruling on merits No 19-P of 1 July 2015. For a recent ruling striking down health laws see Russian Constitutional Court Ruling No 4-P of March 2015.

58 ECtHR, Konstantin Markin v Russia App 30078/06. 
(to much protest) overturned one of its rulings, the Russian Constitutional Court has in general contributed greatly to the alignment of Russian law to ECHR standards. ${ }^{59}$ Since the landmark ruling in Maslov, ${ }^{60}$ in which a judgment was formally supported by the ECHR, the application of the ECHR in Russian courts has increased, and the recognition for international rights norms, although still sometimes contested, has risen very markedly. Between 2000 and 2014, the highest Russian courts - that is the Supreme Court, the Constitutional Court, and the Higher Arbitration Court - cited the ECHR well over 2,000 times, with an accelerated level of citation after $2006 .{ }^{61}$ By 2013 , annual citation of the ECHR by regional courts reached over 6,000 cases. Further, early in Putin's period of influence, extensive reforms of the legal system and the judicial apparatus were implemented, through which international norms were applied to rationalise legal implementation, to reduce arbitrary rulings, and to diminish judicial corruption. This same period saw the introduction of very important domestic legislation to protect civil rights. Important in this respect is the Civil Procedure Code (2002), which sets out procedures for challenging decisions of public authorities and agencies. Notably, one purpose of the Civil Procedure Code was that it facilitated legal challenges to presidential decree, ${ }^{62}$ unlike the USA, for example, Russia knows no doctrine of sovereign immunity. ${ }^{63}$ As a result, the longer era of Putin's dominance has witnessed an exponential rise in the quantity of cases (usually successful) brought to court against public authorities, and the willingness of courts to act against other branches has also increased dramatically. ${ }^{64}$ For instance, Chapter 25 of the Civil Procedure Code gives rise annually to a large number of claims - over 12,000 in 2013. At the time of writing, a new code, the Administrative Litigation Code (2015), is in the process of coming into force, which further simplifies anti-government litigation.

On this basis, we can observe a paradoxical legal situation in contemporary Russia. On one hand, the Russian polity is directed by a partly suspended executive, whose political accountability is restricted. Yet, on the other hand, this executive has actively promoted the solidification of legal counterweights to its authority, and it has promoted and encouraged, or, on the most cautious account, at least wittingly presided over, an expansion of domestic jurisprudence regarding international human rights norms. Of course, this does not mean that Russia is a state marked by uniformly high levels of judicial integrity

59 See S. Y. Marochkin, 'International Law in the Courts of the Russian Federation: Practice of Application' (2007) 6 Chinese Journal of International Law 329, 333, 341; A. Nußberger, 'Wer zitiert wen? - Zur Funktion von Zitaten bei der Herausbildung gemeineuropäischen Verfassungsrechts' (2006) 61 JuristenZeitung 763, 766-767.

60 Russian Constituional Court Decision No 11-П of 27 June 2000.

61 Note that the Higher Arbitration Court was abolished in 2014.

62 This is now covered by separate legislation: Art 2.4.1 of the Federal Constitutional Law No 3-FKZ of 5 February 2014 'On the Supreme Court of the Russian Federation'. This Article states: 'the Supreme Court acts as a court of first instance for consideration of claims challenging normative acts of the President'.

63 See, amongst many other relevant provisions, Article 46(2) of the Constitution and Chapter 5 of the Civil Code (federal Law No. 51-FZ of 30 November 1994. See also for comment A. Trochev, 'Suing Russia at Home' (2012) 59 Problems of Post-Communism 18, 19.

64 On high success rates in Russian anti-government litigation see Trochev, ibid, 18. 
or by unwavering conformity to international norms. But the reception of international law in the national legal system remains a not-negligible factor in Russian politics, and it clearly implies that the courts impose hard constitutional constraints on the executive.

To appreciate the constitutional significance of this paradox, it is necessary to observe the social and institutional context in which Putin's strategies of legal and political reform were initiated. Notably, for much of the 1990s, the Russian body politic approached a condition near to systemic implosion and egregious loss of capacity. ${ }^{65}$ At this time, in particular, private annexation of public offices and public goods was endemic, and the personalisation of public resources had calamitous consequences for the institutional integrity of the state as a political entity. In consequence, throughout the 1990s, structures of reliable and consistent public inclusion in Russia were not easy to identify, and the political system as a whole appeared to be veering towards privatistic dispersal, or even towards a condition of re-feudalisation or state capture, in which oligarchs freely carved up public goods for themselves and their entourage. ${ }^{66}$ Not surprisingly, in consequence, common regard for public media of inclusion, especially the law, was very low, and social demands for resolution and redress were often articulated through informal, private processes. Against this background, on one hand, Putin introduced institutional policies that were designed to promote a vertical strengthening of the executive branch of the state, sometimes with manifestly authoritarian intentions and consequences. At the same time, he pursued far-reaching policies of judicial reform, including, as discussed, measures to reinforce the quality and consistency of the law, and to solidify governmental institutions against powerful private actors. To be sure, Putin's reforms were largely conceived as a strategy for further increasing the infrastructural solidity and autonomy of the executive. ${ }^{67} \mathrm{He}$ stated this intention quite clearly at an early point in the process of judicial reform, declaring that the reforms were required because lack of trust in the state had led to the promotion of 'shadow justice', in which citizens sought remedies for legal problems by private means. ${ }^{68}$ Not by coincidence did Putin announce his programme of judicial reform as part of a plan to create a dictatorship of law. ${ }^{69}$ Moreover, this had particular relevance for the federal structure of the Russian state, which,

65 For expert analysis of the great disasters that befell Russia in the Yeltsin years see S. White, Understanding Russian Politics (Cambridge: CUP, 2011) 138-142.

66 A. Yakovlev, 'The Evolution of Business-State Interaction in Russia: From State Capture to Business Capture' (2006) 58 Europe-Asia Studies 1033, 1033.

67 M. A. Weigle, Russia's Liberal Project. State-Society Relations in the Transition from Communism (University Park, PA: Pennsylvania State University Press, 2000) 272; A. Nußberger, 'Das russische Verfassungsgericht zwischen Recht und Politik' in M. Buhbe and G. Gorzka (eds), Russland heute. Rezentralisierung des Staates unter Putin (Berlin: Spinger, 2007) 215, 228.

68 Annual Address of the President of the Russian Federation to the Federal Assembly, delivered on 3 April 2001. By 2012, Putin claimed that great success had been achieved in ending shadow justice. See Speech of the President of the Russian Federation at the VIII National Congress of Judges, 18 December 2012.

69 See J. Kahn, 'Russia's “"Dictatorship of Law” and the European Court of Human Rights' (2004) 29 Review of Central and East European Law 1; W. Tompson, 'Putin's Challenge: The Politics of Structural Reform in Russia' (2002) 54 Europe-Asia Studies 933, 935-937; P. Solomon, 'Putin's Judicial Reform: Making Judges Accountable as well as Independent' (2002) 11 East European Constitutional Review 117, 123. 
under Yeltsin, had seen a massive haemorrhaging of power from the Russian Federation to the regions and constituent Republics. Putin declaredly pursued judicial reform to reconsolidate a single unified legal space across all parts of the Russian polity. ${ }^{70}$ In addition, however, in view of the institutional environment in which they were implemented, these policies were also designed to heighten the integrity of the political domain, to raise popular trust in the legal system, and to consolidate recognisably public legal structures through society. This assumed great importance in a societal context in which government was defined both recently and historically by acute reliance on patrimony and corruption, and it was part of a broader political endeavour to extract state power from private control: to re-construct state power as meaningfully public or political. ${ }^{71}$

This setting, then, provides a macro-sociological perspective, in which we can address the paradox of Russia's recent relative openness to international law and the resultant expansion of judicial power. In Russia, the penetration of international law into the domestic legal system has had two discernible consequences, both of which have clear constitutional implications, and both of which have impacted directly and constitutively on the political structure of society.

First, we can observe that in Russia the judicial integration of international law in national law reinforces the public distinction of the law, and it provides a legitimating source of authority through which law can be more reliably circulated through society. Clearly, none of this is meant to imply that the Russian state is not still marked by high levels of privatism or clientelism; to contend this would be rather absurd. ${ }^{72}$ However, the fact that courts supervise government actions using international norms means that the political system internalises (however remotely and inconclusively) an originating reference to international human rights law. In turn, this means that the political system can store an abstract image of law's legitimacy, and it can explain the validity of single legal acts by supplying a distinctly public norm to accompany such acts. Despite its historical and residual privatism, therefore, Russian political institutions can use the law to differentiate their decisions from other - more overtly privatised - modes of command in society, and to generalise their own power above the more informal modes of legal exchange which came to proliferate around the political system in the 1990s. Indeed, the fact that laws now have an origin outside the state and are (to some degree) enforceable abstractly against the state means that a dimension of state power remains clearly distinct from private interest, and political organs can apply the law with some reasonable presumption that it will be seen as independent, inclusive, and public. The fact that some laws are underpinned by international rights norms means that the law is clearly elevated above other modes of direction, and it provides a self-construction for the law which hardens the standing of law across society as a formal and relatively autonomous medium of exchange. In Russia, this has

70 One of Putin's most important early orders was Order No 1486 of 10 August 2000: 'On additional measures to ensure the unity of the legal space in the Russian Federation'.

71 See R. Sakwa, 'Putin and the Oligarchs' (2008) 13 New Political Economy 185, 187.

72 See P. Hanson and E. Teague, 'Big Business and the State in Russia' (2005) 57 Europe-Asia 657, 674. 
particular importance because of the fact that, as discussed, legal reform has been promoted as a means for combating local corruption, for extricating law from private patterns of redress in society, and for generalising legal principles across diffuse territories. ${ }^{73}$ The fact that government can split the law, in its normative core, from itself and propose the law as externally legitimised, by international norms, allows the state to project and apply the law as part of a structure of public inclusion. Second, we can observe that the domestic assimilation of international law has produced a marked increase in public confidence in the law, and it means that singular social actors are more likely to choose law over other devices as a medium for dispute settlement. It is no coincidence that recent Russian history has seen a dramatic increase in general levels of litigation. ${ }^{74}$ In itself, this brings social actors into a more immediate relation to institutions of the state, and it again helps to secure the state as a distinct and general fulcrum of social inclusion, constitutionally differentiated from more obviously private organisations.

In both these respects, it appears that, in recent Russian history, the basic principles of judicial constitutionalism have been partially replicated, or selectively filtered, in domestic public law. Distinctively, these principles have been specifically utilised in order to rectify historical problems of weak articulation and precarious inclusionary structure in the Russian political system. Distinctively, moreover, these principles have been used, if judged by common categories, to underpin an emphatically political constitution. On one hand, the current Russian polity looks back to a classical model of semi-Caesaristic constitutionalism, in which the government adopted a thin legal form in order to rationalise the power of a semi-detached executive. On the other hand, the Russian legal/political system as a whole is now constituted, in part, by the inflow of international human rights norms, which the executive appears to accept as necessary, and which provide a basis through society for the stabilisation of the political system and - in fact - for the abstraction of political structure per se. Most particularly, we can observe that in Russia international human rights are constructed and applied, by judiciaries, politically: they act as originating sources of legitimacy for the political system, they are preserved and enforced alongside more classical patterns of political institution building and agency, and they allow other organs of public order to obtain more solid foundations in society. Naturally, the Russian constitution remains an incompletely enforced constitution. However, it illuminates distinctively a particular hybridising tendency in contemporary constitution making. As discussed, it is an example of an executive-led political constitution, in which the assimilation of international law is endorsed and promoted because it allows the executive

73 Notably, one outcome of Putin's reforms has been an increase in the citation of human rights norms in regional courts, suggesting that the assimilation of international law increases the consistency of the relation between higher courts and regional courts.

74 On increasing production of law in Russia see R. Sakwa, 'The Dual State in Russia' (2010) 26 Post-Soviet Affairs 185, 201. For statistics see K. Hendley, "“Telephone Law" and the "Rule of Law": The Russian Case' (2009) 1 Hague Journal on the Rule of Law 241, 243. Civil law cases rose from 2881.6 in 1997 to 9009.0 in 2007. Hendley also notes increasing confidence in law as an instrument for protecting rights (ibid, 244). 
to cement and presuppose an autonomous public/political structure in society. A judicial constitution based in international law thus forms the constitutional basis for the effective, public exercise of power by the political executive.

\section{Kenya}

A more unambiguous example of the hybridisation of judicial and political constitutionalism and of the judicial use of international law as a source of political agency is visible in the recent process of democratic constitutional transition in Kenya.

In approaching the case of Kenya, first, it is notable that the Kenyan state also had a history of acute structural weakness, and its ability to penetrate into, and effectively to co-ordinate, society was low. This was of course a feature of most post-colonial states in Africa. However, this low capacity was exacerbated by the fact that through the 1960s and 1970s the Kenyan polity developed a strong corporatist bias, which meant that actors in the political system endeavoured to manufacture legitimacy for policy making by internally reconciling the interests and divergent objectives of rival socio-economic groups. ${ }^{75}$ One consequence of this was that the state was forced to serve as a clearing-house for the prerogatives of different economic organisations, and of leading individuals within these organisations, and it was marked by high porosity to private interests. ${ }^{76}$ Most notably, however, the fragility of the Kenyan state was a result of the fact that it was exposed to volatile ethnic fissures, and the government was only able to generate limited support by appealing to national interests, tending to acquire compliance for its laws by allocating privileges to distinct sub-national groups and by ensuring selective ethnic hegemony in society. ${ }^{77}$ The underlying tribalisation of government also had the consequence that state authority had curtailed purchase in society, and the foundations of support for the political system were partially privatised, or derived from benefices and rewards for ethnic affiliation and group support. ${ }^{78}$ Although it was more robust than some post-colonial African states, the governmental system in Kenya, historically, shared many common characteristics typical of post-colonial states, notably low capacity, low institutional density, high levels of corruption (especially judicial corruption), and patchy social reach. ${ }^{79}$

75 C. Leys, Underdevelopment in Kenya. The Political Economy of Neo-Colonialism 1964-1971 (London: Heinemann, 1975) 222.

76 See R. Sandbrook, 'The State and the Development of Trade Unionism' in G. Hyden, R. Jackson and J. Okumu (eds), Development Administration. The Kenyan Experience (Nairobi: OUP, 1970) 252; H. Bienen, Kenya: The Politics of Participation and Control (Princeton, NJ: Princeton University Press, 1977) 23.

77 A. Bannon, 'Designing a Constitution-Drafting Process: Lessons from Kenya' (2007) 116 Yale Law Journal 1824, 1831; S. D. Ross, 'The Rule of Law and Lawyers in Kenya' (1992) 30 Journal of Modern African Studies 421, 440; J. W. Harbeson, Nation-Building in Kenya. The Role of Land Reform (Evanston: Northwestern University Press, 1973) 103.

78 S. N. Ndegwa, 'Citizenship and Ethnicity: An Examination of Two Transition Moments in Kenyan Politics' (1997) 91 The American Political Science Review 599, 612.

79 M. S. Grindle, Challenging the State: Crisis and Innovation in Latin America and Africa (Cambridge: CUP, 1996) 79. Grindle argues that by the 1980s the 'authoritativeness and legitimacy' of the 
The constitutional trajectory followed by Kenya in its recent transition towards democracy can be partly interpreted against this background. In the first instance, reform of the political system was (very reluctantly) promoted through the 1990s by the incumbent President Moi, who was surrounded by a coterie of political, often ethnically affiliated, allies. ${ }^{80}$ In the first instance, Moi accepted transition to multi-party elections in 1992, which, partly because of ethnic fissures in the opposition, he won. Ultimately, in the later 1990s, Moi acceded to the creation of a new constitution. Originally, it was proposed that the new constitution would be drafted by the Constitution of Kenya Review Commission (CKRC), and endorsed by a National Constitutional Conference, criteria for membership in which were set by the sitting parliament itself. ${ }^{81}$ The draft constitution that was produced in 2004 (the Bomas draft) already possessed a strong judicial dimension, and it clearly envisaged that access to justice was a vital part of the transition and that judicial power could be used to cement a direct link between the political system and national citizens. For example, the Bomas draft provided for the establishment of a High Court, authorized in Article 32 to hear human rights cases. In Article 31, it foresaw that a large array of parties would be able to initiate human rights litigation. In Article 29(4)(a) it stated that, when applying human rights, courts were obliged to "promote the values that underlie an open and democratic society based on human dignity, equality, equity and freedom', thus conferring a strongly purposive role on the courts. At an early stage, however, the process of constitution making was re-directed, also in a fashion which accentuated the judicial emphasis of the transition as a whole. In 2004, notably, the constitution-making process was challenged in judicial proceedings, as a result of which judicial bodies, in part supporting their interventions through reference to international law, entered the dynamic of constitution making as immediately implicated actors.

Judicial intervention in the transitional process became especially prominent in the public-interest case, Njoya and Others $\mathrm{v}$ Attorney General and Others ${ }^{82}$ (Njoya). In this case, the authority of the National Constitutional Conference to approve a new constitution was contested before the High Court. Significantly, the applicants argued that the parliament, via the Conference, was not entitled to claim the right to exercise constituent power, and a new constitution could not be accorded validity by a sitting government. In addition, the applicants protested against the dismemberment of the Kenyan nation into separate electoral districts during the writing of the constitution, claiming that this accorded undue privilege to distinct ethnic groups, and generally impeded the formation of a nationally legitimated constitution. Ultimately, the court

Kenyan state were 'under siege' (ibid, 184). On judicial corruption under Moi, see P. Nowrojee, 'The Legal Profession 1963-2013: All This Can Happen Again - Soon' in Y. Pal Ghai and J. Cottrell (eds), The Legal Profession and the New Constitutional Order in Kenya (Nairobi: Strathmore University Press, 2014) 33, 37.

80 See details of the ethnic composition of Moi's cabinets in K. Kanyinga, 'Pluralism, Ethnicity and Governance in Kenya' in Y. Pal Ghai and J. Cottrell (eds), Ethnicity, Nationhood and Pluralism: Kenyan Perspectives (Nairobi: Katiba Institute, 2013) 47, 59.

81 See P. Kameri Mbote and M. Akech, Kenya: Justice Sector and the Rule of Law (Johannesburg: Open Society Initiative for Eastern Africa, 2011) 35.

82 Njoya and Others v Attorney-General and Others (2004) AHRLR 157 (KeHC 2004). 
found in favour of the applicants. The Justices argued that a new constitution could only acquire legitimacy if it were established by a higher-order political will, and it needed to extract its authority from the single and sovereign national people, acting, not as a parliamentary assembly, but as a primary constituent power. Decisively, the Court ruled that 'every person in Kenya' had an 'equal right to review the constitution' and even to participate 'in writing and ratifying the Constitution'. In marked contrast to conventional jurisprudence in Kenya, which had usually accentuated the primacy of domestic law in over international law, ${ }^{83}$ the Court also cited Article 21 of the Universal Declaration of Human Rights to reject the apparent discriminatory composition of the constitution-making body. ${ }^{84}$ On this basis, the court determined that a referendum was required to endorse the constitution. It was concluded that the applicants possessed a 'constituent right' to 'adopt and ratify a new Constitution' and even that this right was the 'centre-piece of a people-driven constitutional review process' ${ }^{85}$ The collective right to exercise constituent power assumed particular weight, the court argued, because of the regionalistic bias of the Constitutional Conference, which, allegedly, sought to 'fragment and Balkanize the Republic of Kenya into ethnic mini-states' ${ }^{86}$ In the first instance, this ruling led to the writing of a second draft constitution (the Wako draft), which was rejected in a referendum in 2005. A new democratic constitution for Kenya was not finally approved and ratified until 2010.

The 2004 ruling in Njoya remains highly contested in Kenyan politics. It is widely assumed that the challenge to the Bomas draft was orchestrated by President Kibaki in order to re-route the process of democratisation, which, through the CKRC, under the leadership of Yash Pal Ghai, had promoted consultation with a broad range of stakeholders and organisations. ${ }^{87}$ As a result, arguably, this case withdrew momentum from the reform process, and it allowed ethnic tensions to assume renewed intensity, culminating in the acute post-election violence of $2007 .{ }^{88}$ In the Njoya ruling, nonetheless, the

83 For a long time, Okunda v Republic [1970] EA 453, in which international law was ruled subordinate to domestic law, remained a leading case regarding the status of international law. This approach was sustained in later leading cases, in Rono v Rono (29 April 2005) Civil Appeal No 66 of 2002 [2008] 1 KLR 803. However, this position changed gradually in the course of the transition. For example, in In Re Estate of Lerionka Ole Ntutu (Deceased) [2008] eKLR, the Kenyan High Court announced that it would adopt a more purposive 'living tree' approach to constitutional interpretation, citing international covenants to overrule customary law. The line of reasoning in Rono v Rono was abandoned in later cases, in particular in Satrose Ayuma and others v The Registered Trustees of the Kenya Railway Staff Benefits Scheme and others (High Court petition no 65 of 2010), where the Justices ruled that the principle stated in Rono v Rono was not 'good law'. Note though that before 2010 some rulings had already given particular weight to international law. An important example is In Re the Estate of Andrew Manunzyu Musyoka (Deceased) [2005] eKLR.

84 Kenya Law Reports [2004] 1 KLR 237. On the importance of international law in this case see Mbote and Akech, $\mathrm{n} 81$ above, 39.

85 ibid, 238.

86 ibid, 239.

87 B. J. Berman, J. Cottrell and Y. Ghai, 'Patrons, Clients, and Constitutions: Ethnic Politics and Political Reform in Kenya' (2009) 43 Canadian Journal of African Studies 462, 493.

88 On the 're-emergence of political tribalism' under Kibaki, see G. R. Murunga and S. W. Nasong'o, 'Bent on Self-Destruction: The Kibaki regime in Kenya' (2006) 24 Journal of Contemporary African Studies 1, 10. 
Court still enunciated certain vital, even revolutionary principles, which had an enduring impact on the process of transition. ${ }^{89}$ First, the Court came to the conclusion that, of itself, it was authorised to allocate political rights, and in fact to identify and to circumscribe the locus and the scope of national constitution-making power. In this respect, the court assumed and established powers to subject the process of constitution writing to judicial review which were not yet constitutionally extant, and so, in determining the necessity of a referendum for securing constitutional legitimacy, it accorded itself proprio motu constituent force. ${ }^{90}$ Indeed, the court strategically directed the Kenyan constitution away from the Westminster-based design projected in the Bomas draft towards a more presidential model. Second, the court responded to the historically unsettling ethnic landscape of Kenyan society by insisting on, and in fact constructing, a source of national constituent agency standing above or behind the different ethnic sub-groups in society, and by - albeit momentarily - locating that agency in itself. ${ }^{91}$ The political nation was thus defined by, and placed in the guardianship of, the court. In this respect, the court, strongly backed by presumptions regarding international political rights, positioned itself as the supreme centre of general political volition, and it claimed to project a political structure against the privatistic interests which had traditionally eroded abstracted public-legal norms in Kenyan society.

The Kenyan constitution that was ratified in 2010 is conceived as an intensely political, deeply transformative constitutional document, which far exceeds classical liberal models of limited constitutional organisation. In numerous respects, in particular, the constitution is designed as a programmatic endeavour to transform the pluralistic reality of Kenyan society into a unified political nation under law, condensing national sovereign power into a clearly articulated form. Notably, in Article 10(1), the constitution expressly assigns to itself a nationally consolidating role, prescribing a body of substantive values, including dignity, equity, social justice, and respect for human rights, as principles to unify society, and to bind all public organs, at all societal levels. The underlying unifying objectives of the Constitution are also underscored by provisions for extensive social and economic rights (Article 43). At the same time, however, the transformative political impulse of the constitution did not preclude endorsement of many broader hallmarks of judicial constitutionalism. ${ }^{92}$ On the

89 On this, I share the opinion of my friend and colleague, the Kenyan constitutional expert John Osogo Ambani, who describes the Njoya case as 'bad politics but good law', which, despite its background, ultimately had revolutionary implications and consequences. (Conversation with the author, 5 November 2015).

90 Kenya Law Reports [2004] 1 KLR 233. For comment see L. Juma and C. Okpaluba, 'Judicial Intervention in Kenya's Constitutional Review Process' (2012) 11 Washington University Global Studies Law Review 287, 312.

91 Kenya Law Reports [2004] 1 KLR 239. The Court later offered a further definition of the constituent power, again assuming the right to define conditions of its adequate exercise. See Onyango \& 12 others v Attorney General \& 2 Others [2008] 3 KLR 175.

92 One leading Kenyan judge argues accordingly: 'One cannot achieve constitutionalism without giving effect to its attendant ideology: judicialism': J. B. Ojwang, Ascendant Judiciary in East Africa. Reconfiguring the Balance of Power in a Democratizing Constitutional Order (Nairobi: Strathmore University Press, 2013) 40. 
contrary, in fact, the 2010 Constitution reflects the general judicial emphasis of the longer transition. For example, Article 160 of the constitution emphasises the necessity of the autonomy of the judiciary in relation to the executive. Article 163 (1) establishes a Supreme Court, and Article 168 accords particular protection to the independence and tenure of judges. ${ }^{93}$ Article 23(1) creates a High Court with jurisdiction for violations of human rights and fundamental freedoms. Moreover, the Constitution also attributes distinctive nation-making functions to judicial actors. For example, Article 259 imputes a distinctive purposive role to the judiciary, and it directs the judiciary to promote the values and purposes inherent in the constitution, and constructively to develop the law on that basis. Article 261 (5-7) implicitly assigns a mandate to the judiciary to instruct parliament, where necessary, to pass bills implementing constitutional values and provisions. These provisions were intended, at one level, to elaborate general legal consciousness as a normative foundation for social life. But they were also intended to ensure that the judiciary played a leading structurebuilding role in society. On this foundation, the courts continued to promote a purposive model of legal interpretation, and they assumed a self-consciously active role in the formation of law and the consolidation of the constitution. ${ }^{94}$ In one case, in fact, the court declared that the judiciary had acquired a 'pivotal' role 'in midwifing transformative constitutionalism and the new rule of law'. 95 Notably, further, Articles 3(1) and 22 provide that every citizen is authorised to litigate to defend the constitution, so that the constitution was constructed as a direct link between individual persons, situated at different locations in society, and the national government.

Alongside this, the 2010 Constitution also marks a 'revolutionary' break with Kenya's traditional common-law, dualist approach to international norms, ${ }^{96}$ and

93 See M. Akech, 'Abuse of Power and Corruption in Kenya: Will the New Constitution Enhance Government Accountability?' (2011) 18 Indiana Journal of Global Legal Studies 341, 390.

94 See Beatrice Wanjiku \& Another v Attorney General \& Another [2012] eKLR. In this case, a purposive approach to legal interpretation was expressly encouraged. Note, however, that this did not entail any ascription of primacy to international law. On the contrary, the following statement of principle was made: "Although it is generally expected that the government through its executive ratifies international instruments in good faith on the behalf of and in the best interests of the citizens, I do not think the framers of the Constitution would have intended that international conventions and treaties should be superior to local legislation and take precedence over laws enacted by their chosen representatives under the provisions of Article 94', ibid, 6-7.

95 Kenyan Supreme Court, Communications Commission of Kenya \& 5 others v Royal Media Services Limited \& 5 others 2014] eKLR 66.

96 M. Oduor, 'The Status of International Law in Kenya' (2014) 2 Africa Nazarene University Law Journal 97, 98. Ambiguities in the reception of international law after 2010 are assessed in M. Kiwinda Mbondenyi, and J. Osogo Ambani, The New Constitution of Kenya. Principles, Government and Human Rights (Nairobi: LawAfrica Publishing, 2013) 33. Notably, the current Chief Justice, Willy Mutunga, has argued that Kenya has become 'a monist state rather than a dualist one': ttp://kenyalaw.org/kenyalawblog/keynote-speech-for-the-africa-and-internationallaw-conference/ (last accessed 10 November 2015). This view has also been supported by the governmental human rights commission. But the location of international laws in the hierarchy of domestic legal norms has not been finally clarified. See, for critique, T. Kabau and J. Osogo Ambani, 'The 2010 Constitution and the Application of International Law in Kenya: A Case of Migration to Monism or Regression to Dualism?' (2013) 1 Africa Nazarene University Law Journal 36, 49. 
to human rights law more generally. ${ }^{97}$ In fact, the background to the implementation of the final constitution in Kenya was deeply shaped by an opening of Kenyan law to international law. Amongst other factors, this related to the ethnic violence following the elections in 2007, which meant that the process of constitutional reform was placed under the scrutiny of the International Criminal Court (ICC). One result of this was that international criminal law, as well as international human rights norms, was systematically integrated into domestic law, notably in the International Crimes Act (2008). ${ }^{98}$ This international-legal emphasis is displayed in constitutional provisions (Articles 2(5) and 2(6)) for the domestic application of international law, which mean that the purposive functions of the courts are in part attached to their responsibility for the domestic assimilation of international law. After the constitution took effect, then, the assimilation of international law was pursued extensively by the high judiciary, which consciously promoted the incorporation, although not, or at least not uniformly, the supremacy, of international law, and especially international human rights conventions, within the municipal legal system..$^{99}$ In early cases after 2010, for example, the High Court in Nairobi ruled that international human rights treaties are part of domestic law, and can be used to overrule domestic statutes. ${ }^{100}$ More notably, the High Court also claimed jurisdiction over cases involving breaches of international jus cogens, claiming both that general rules of international law are part of Kenyan law, and that some clauses of the Constitution, especially Article 159(2)(e), must be developed through recognition of international law in conjunction with other nations. ${ }^{101}$

Naturally, we can only speculate what the final outcome of the Kenyan transition will be. In some ways, the judicial reinforcement of constituent power during the earlier part of the transition had a counter-intentional effect. As mentioned, after 2004, the constitution-making process was surrounded by ethnic tensions, especially in the post-election violence of 2007-2008, and it

97 For the key example of traditional judicial reluctance in the application of human rights laws, see Kenyan High Court, Joseph Maina Mbacha \& Three Others v The Attorney General (High Court Misc Application No 356 of 1989). For general comment on the traditional 'deference' of the Kenyan courts to the executive in human rights questions, see J. B. Ojwang and J. A. Otieno-Odek, 'The Judiciary in Sensitive Areas of Public Law: Emerging Approaches to Human Rights Litigation in Kenya' (1988) 35 Netherlands International Law Review 29, 49.

98 A. Okuta, 'National Legislation for Prosecution of International Crimes in Kenya' (2009) 7 Journal of International Criminal Justice 1063, 1072. See the excellent analysis of this point by Elizabeth O'Loughlin (PhD researcher, University of Manchester).

99 See T. Kabau and C. Njoroge, 'The Application of International Law in Kenya under the 2010 Constitution: Critical Issues in the Harmonization of the Legal System' (2011) 44 Comparative and International Law Journal of Southern 293, 294-295. This reception is observed more critically in M. Wabwile, 'The Emerging Juridical Status of International Law in Kenya' (2013) 13 Oxford University Commonwealth Law Journal 167, 181; Oduor, n 96 above, 98.

100 In Re The Matter of Zipporah Wambui Mathara [2010] eKLR. Elsewhere the Court of Appeal opined as follows: 'Kenya is traditionally a dualist system, thus treaty provisions do not have immediate effect in domestic law nor do they provide a basis upon which an action may be commenced in domestic courts. For international law to become part and parcel of national law, incorporation is necessary, either by new legislation, amended legislation or existing legislation. However, this position may have changed after the coming into force of our new Constitution': David Njoroge Macharia v Republic [2011] eKLR.

101 Kenya Section of The International Commission of Jurists v Attorney General \& another [2011] eKLR 15. 
led to a clear fragmentation of state structure. Moreover, the resultant proceedings in the ICC, leading to the decision in the Kenyan parliament to withdraw from the Statute of Rome, are often perceived as having reduced the scope and stability of political democracy in Kenya. ${ }^{102}$ Further, there is ample evidence that the constitutional reforms have done little to resolve more traditional structural problems, in particular endemic judicial corruption. ${ }^{103}$ Nonetheless, we might observe that in Kenya the reception of international human rights norms and the ensuing rise in judicial power more generally have provided a hybrid basis for a national political structure. These processes have created a setting in which the exercise of more classical patterns of political volition has been facilitated, counteracting the traditional obstructions to the formation of a distinct system of political inclusion. In the Kenyan setting, the judicial implementation of rights norms clearly formed an element of the national constituent power, and judicially applied norms have actively underscored the emergence of the national political order as a distinctive and politically constituted inclusionary structure. ${ }^{104}$ Over a longer period of time, in fact, the judicial construction of constituent power remained palpable and active in changing legal practices in Kenya, and judicial procedures retained an inclusionary, politically formative, quality. Following the challenges to the constitution-making process in 2004, for example, public-interest litigation, often based in international human rights law, was subject to increasing formal-legal protection, ${ }^{105}$ it became a prominent political, even quasi-constituent force, and it proved an important channel for the transmission of demands from different locations in society into the political system. ${ }^{106}$ Indeed, public-interest litigation acquired very notable

102 See S. D. Mueller, 'Kenya and the International Criminal Court (ICC): Politics, the Election and the Law' (2014) 8 Journal of Eastern African Studies 25, 38.

103 This is openly acknowledged by Willy Mutunga the current Chief Justice. See http://www. nation.co.ke/news/-/1056/2818292/-/146dr5sz/-/index.html (last accessed 10 November 2015).

104 On some accounts, in fact, a classical constituent power never came into being, and national participation in constitution making was minimal. See J. Mukuna and M. L. M. Mbao, "We the People": On Popular Participation and the Making of the 2010 Constitution of Kenya' (2014) 5 Mediterranean Journal of Social Science 85, 91.

105 Wide rules on standing were established (under Moi) in the Environment Management and Co-ordination Act of 1999 (3(4)), which subsequently had a significant effect on assumptions concerning standing in different areas of the law.

106 After 2004, the courts were prepared to make broad provisions for public-interest litigation and even to argue that standing is justified for public-interest litigation in cases where 'great constitutional and public law issues' are raised. See Onyango \& 12 others v Attorney General \& 2 Others [2008] 3 KLR 175. Public interest litigation obtained constitutional protection in the 2010 Constitution, Arts 22(2) and 258(2). After 2010, the High Court showed great innovation in developing principles of public-interest litigation. On one hand, it applied international human rights law to give weight to its approval of public-interest petitions, thus encouraging publicinterest litigation as a domestic articulation of international norms. On the other hand, it argued that public-interest litigation was specifically justified by the fact that constitutional rights were binding both on public and private actors, and that all persons violated in their rights had justified recourse to the courts. For these arguments, see Satrose Ayuma and others v The Registered Trustees of the Kenya Railway Staff Benefits Scheme and others [2011] eKLR. In each respect, public-interest litigation acted as a distinct form of constituent power, widening the domain of national constitutional law in society, and the judiciary expanded the sources of agency able to construct political laws. For important comment on the changing role of the Kenyan judiciary in this respect, see 
importance for attempts to challenge the conventional ethnic bias of the political system, thus assuming an intrinsically integrative, nation-building role in society. ${ }^{107}$ In these respects, courts partly retained their position as organs of a measured constituent power, and international human rights law continued to act as a source of general political structure, broadening the inclusionary force of the political system across society.

\section{Bolivia}

An equally striking case of hybrid national/international or political/judicial constitution writing is evident in the recent process of constitutional reform in Bolivia, culminating in the constitution of 2009, implemented by Evo Morales.

In this case, once again, it is notable that the Bolivian political system was historically characterised by low institutional density, and weak penetration into society, and it did not operate in an environment of cohesive nationhood. ${ }^{108}$ Moreover, the political system was affected by very unsettling levels of clientelism, patrimonialism, and privatistic control of public offices. ${ }^{109}$ This was partly caused by the corporatistic design of the Bolivian constitution created in 1952, instituted after the national revolution, aspects of which were later preserved in more authoritarian form after the military coup of 1964 and in the dictatorship of the 1970s. ${ }^{110}$ However, as in Kenya, the inner privatism of the Bolivian political system was also caused by the pluralistic ethnic structure of Bolivian society, which meant that the integrative powers of the state remained low and its support remained piecemeal and precarious. Notably, the democratic corporatist state in Bolivia was conceived, in part, as an instrument to impose a unified national legal structure across all society, and it was intended to place different peripheral communities, often with distinct ethnic attachments, in a direct relation to the central state. One important account of the state established in 1952 claims that corporatism was designed to serve the uniform 'radiation' of state power across the fissures of an ethnically complex

B. Sang YK, 'Tending towards Greater Eco-Protection in Kenya: Public Interest Environmental Litigation and its Prospects within the New Constitutional Order' (2013) 57 Journal of African Law $29,40$.

107 Public-interest litigation became a vehicle for asserting rights of protection for ethnic groups in a number of cases, both in national courts and in the African Court and the African Commission on Human and Peoples' Rights. An important recent example of a case in the African Court regarding minority-community rights against Kenya is the African Commission on Human and Peoples' Rights v The Republic of Kenya Appl no 006/2012. Importantly, although the petition in question was itself unsuccessful, the Kenyan High Court at Nairobi has ruled that land claims can have constitutional significance, thus creating a legal opening for such claims to shape public law. See Ledidi Ole Tauta \& Others v Attorney General \& 2 others [2015] eKLR.

108 A. I. Balenciaga, La democracia en Bolivia (La Paz: Plural, 2012) 56-57. See also Inter-American Commission on Human Rights, Access to Justice and Social Inclusion: The Road Towards Strengthening Democracy in Bolivia (Washington, DC: General Secretariat Organization of American States, 2007) 3.

109 World Bank, Bolivia: From Patronage to a Professional State (Washington, DC: World Bank, 2000) vii, 43, 60; Malloy, n 39 above, 470-471.

110 A. García, 'Los sindicatos en el esquema de revolución nacional: El sindicalismo en la experiencia boliviana de nacionalización y desarrolo' (1996) 33 El triestre económico 597, 598, 606; Balenciaga, n 108 above, 112. 
national society. ${ }^{111}$ A central part of this state-building strategy was the fact that, in the corporatist state, trade unions were ascribed a prominent, in fact co-governmental, role in the political system, and the government ordered the working population in class-based professional syndicates, which often assumed political functions. In this respect, the corporatist state was meant to ensure that different ethnic communities identified, not with their regional communities, but with their class or their profession, and that they were linked immediately to the state through class-based or professional loyalties, identities, and associations. ${ }^{112}$ In each respect, the corporatist system was expected weaken the pull of lateral ethnic affiliations against the central force of the national government. ${ }^{113}$ Despite the uniform integrationist appeals of the corporate apparatus, however, rural communities with large indigenous contingents generally only obtained positions of marginal integration, standing in the shadow of more powerful mining unions, and society as a whole remained very 'weakly integrated'. 114 Accordingly, the process of constitutional reform, starting in the early 1990s, assuming interim expression in the constitutional reforms of 1994 and 2004, and completed in 2009, was focused in part on raising state capacity and on broadening the inclusionary force of the political system. The corporatist system had been partly abandoned in the 1980s. ${ }^{115}$ Moreover, after 2005 trade unions again became an important platform for the national government. Nonetheless, the later constitutional reforms were clearly concerned with building a general foundation for the state in a context in which state-corporatist constitutionalism had failed to solidify a basic structure of inclusion, and had left a damaging legacy including hyperpoliticisation of the state, party-political corruption, and endemic prebendalism. ${ }^{116}$

At face value, the 2009 Bolivian constitution only falls marginally into the category of judicial constitutionalism. In contrast to the other settings considered here, this constitution was in some respects written in a spirit of hostility to international law. The Bolivian Constitution, notably, declares that the constitution itself, expressing the manifest will of the national people, is the highest source of norms in the state (Article 410), and it prohibits the use of international law to override domestic law, especially in economic disputes. ${ }^{117}$ Moreover, this constitution is sceptical about sanctioning strong and

111 Á. García Línera, La condícion obrera en Bolivia. Siglo XX (La Paz: Plural, 2014) 199.

112 See R. W. Patch, 'Bolivia: The Restrained Revolution' (1961) 334 Annals of the American Academy 123, 125.

113 See J. A. Lucero, Struggles of Voice: The Politics of Indigenous Representation in the Andes (Pittsburgh, PA: University of Pittsburgh Press, 2008) 66; J. Lazarte, Movimento obrero y procesos politicos en Bolivia. Historia de la C.O.B. 1952-1987 (La Paz: EDOBOL, 1989) 188.

114 C. M. Vilas, 'Participation, Inequality and the Whereabouts of Democracy' in D. A. Chalmers, C. M. Vilas, K. Hite and S. B. Marti (eds), The New Politics of Inequality in Latin America: Rethinking Participation and Representation (Oxford: OUP, 1997) 3.

115 See Línera, n 111 above, 140.

116 In agreement with this view see C. H. Molina Saucedo, De la Participación Popular al Estado de las Autonomías (Santa Cruz: CEPAD, 2015) 165.

117 A very potent factor in the background to the new constitution was the 'guerra del gas' of the early to mid-2000s, in which different social groups mobilised against export of vital natural resources, and the government used military force in an attempt to suppress the protests. In this process, the weakness of state institutions, and their lack of national support, became clear. Generally, 
autonomous judicial institutions. In fact, secure judicial independence is not a pronounced feature of government in the Bolivian political system, both historically and now under Morales. ${ }^{118}$ In Article 196, the constitution stipulates that the Constitutional Court (operative from 1999) is bound to the will of the national constituent power, and the national constituent power, rather than any abstracted norms, is to be recognised by the courts as the most authoritative criterion for interpretation of laws. This principle has been upheld by courts, and it has meant that judges have often lacked willingness to challenge acts of political legislation. On occasions, in fact, Bolivian judges have reflected at length on the doctrine of national constituent power, which they define as a power with an 'original, autonomous, extraordinary and extra-judicial character', such that it is not subject to constitutional control or judicial review. ${ }^{119}$ This doctrine has provided support for executive decisions to make changes to important political laws, including the law on presidential elections, and it has been used, effectively, to allow the sitting government to act as a constituent power. ${ }^{120}$ Furthermore, the Bolivian constitution contains little of the reserved attitude towards programmatic material and economic rights that is evident in other contemporary judicial constitutions. On the contrary, its formation was driven by a very expansive momentum for socio-economic inclusion. ${ }^{121}$ It contains extensive provisions for material rights, and it expresses a deep contempt towards the formality of liberal economic rights, emphatically rejecting economic policies reflecting ideals linked to (what is usually defined as) neoliberalism. ${ }^{122}$ The constitution is in fact pervaded by a deep commitment to ensuring that all groups in society, especially members of minority or prior populations, are guaranteed equal professional rights, equal rights in access to law, and even that they participate in processes of political will formation underpinning single acts of legislation. Notably, the constitution was written by a diversely configured constituent assembly, containing representatives of many sub-national groups, and it is programmatically described in its preamble as a plurinational constitution. Under this constitution, members of pre-national population groups have been formally allocated collective rights of national representation and collective rights of self-government. ${ }^{123}$ Provisions are also

the constitutional settlement of 2009 was a reaction to a deep and long-standing polarisation of society caused by divisions between social groups in resource-rich areas who benefited from the export economy and social groups dependent on local exploitation of resources.

118 See W. Herrera Añez, El Estado de la Justicia Boliviana. Del Estado Republicano al Estado Plurinacional (Cochabamba: Kipus, 2013) 26, 32, 51.

119 Bolivian Constitutional Court 0168/2010-R, 16.

120 Bolivian Constitutional Court, Declaration 0003/2013.

121 F. Gamboa Rocabado, 'Transformaciones constitucionales en Bolivia. Estado indígena y conflictos regionales' (2010) 71 Colombia internacional 151, 162.

122 The Preamble to the Constitution declares as follows: 'We have left the colonial, republican and neo-liberal State in the past. We take on the historic challenge of collectively constructing a Unified Social State of Pluri-National Communitarian law, which includes and articulates the goal of advancing toward a democratic, productive, peace-loving and peaceful Bolivia, committed to the full development and free determination of the peoples.'

123 Note that at the time of writing the promises of indigenous autonomy in the Constitution have not been realised, although some forms of self-government have been established. The main progress in granting indigenous rights in Bolivia is evident in the increased access of indigenous communities to professions, and in their increased equality before law. 
made for the preservation of communal justice and customary law in regions inhabited by prior populations (Articles 190-192). In some respects, in fact, the Bolivian constitution, like those of Venezuela and Ecuador, ${ }^{124}$ is designed to preserve the presence of a live associational constituent power in the state, and to ensure that the state is constantly sensibilised to, and even reconfigured by, the plural constituencies that it contains. This obviously sits uneasily with conventional ideas of the rule of law, and it instils a highly charged political constellation at the centre of the public legal order. ${ }^{125}$ Partly for this reason, since 2009 a political reality has evolved under Morales in which the government relies more on societal populism than on formal law for support, and Morales has at times placed far-reaching restrictions on judicial autonomy. Accordingly, one analysis defines post-2009 Bolivia as an 'authoritarian democracy'. ${ }^{126}$ Overall, in sum, this constitution is in key respects a highly politicised constitution, produced through intense conflicts between different social sectors and different ethnic groups. As a result, it expressly endeavours to channel a complexly configured political will through the formal apparatus of the state, and to ensure that the government is closely bound to the dictates of this will.

Despite this, nonetheless, there are certain ways in which even the Bolivian constitution extracts its authority from a constructive fusion of national and international law. In fact, like other constitutions considered above, it hybridises elements of judicial and political constitutionalism to remedy historically corrosive problems of political structure and political-systemic abstraction.

On one level, for example, despite its emphatic commitment to the exercise of constituent power, the Bolivian constitution ultimately accords suprapositive standing to international human rights law. In Article 256, it implicitly places international human rights treaties above domestic constitutional law, especially where treaties offer stronger protection for human rights than domestic law. Article 410(2) also implies a doctrine of the block of constitutionality, widespread in the jurisprudence of many superior Latin American courts, which construes international human rights treaties and customary international law as part of the domestic constitution. These provisions have only been selectively enforced, and the Constitutional Court has at times rejected arguments founded in international law. ${ }^{127}$ However, these norms have been upheld in some important rulings of the Constitutional Court. ${ }^{128}$ In one case, the Constitutional Court argued that rulings of the Inter-American Court of Human Rights (IACtHR) should be viewed as parts of the block of constitutionality. ${ }^{129}$ Notably, further, international norms have been used

124 H. N. Alcalá, 'Consideraciones sobre poder constituyente y reforma de la constitución en la teoría y la práctica constitucional' (2010) 15 Revista ius et praxis 229, 237.

125 See J. Lazarte, Reforma del "experimento" constitucional en Bolivia (La Paz: Plural, 2015) 106.

126 Balenciaga, n 108 above, 186.

127 See decision 0408/2014-CA. Judges on the Constitutional Court reflected openly on these ambiguities in $0260 / 2014,5$.

128 See ruling 0323/2014. In 0778/2014, which restricted indigenous rights, the American Convention on Human Rights was declared part of the domestic block of constitutionality.

129 This was declared in 0110/2010-R. The judges argued here as follows: 'the doctrine of the block of constitutionality recognized by Art 410 of the Constitution sees International Treaties 
to circumscribe the judicial autonomy of indigenous populations, ${ }^{130}$ and, with the exception of very remote communities, the practice of communal justice in indigenous societies remains restricted by general norms of public law. In the final analysis, this means that the will of the political nation, even in subnational communities, is not categorically released from prior constraints, and it must under some circumstances be proportioned to, or judicially overruled by, pre-established international norms.

In addition, the pluralistic, locally embedded foundation of the state has its origin - to a large extent - in international law. The promotion of plurinational constitutionalism in Bolivia was first shaped by a series of norms produced in the international domain. On one hand, the advent of plurinational constitutionalism was shaped by landmark rulings of the IACtHR, which clearly recognised the autonomy and integrity of prior populations. ${ }^{131}$ On the other hand, the new line of multi-focal constitutional practice in Bolivia was guided by the provisions of Convention 169 (1989) of the International Labour Organization (ILO), which declared that prior populations were entitled to claim separate rights of self-government. ${ }^{132}$ Convention 169 was drafted by the Bolivian Ambassador to the ILO, and Bolivia has elevated its provisions to constitutional rank in domestic law. ${ }^{133}$ Shortly after the endorsement of the ILO Convention, the (at that time liberal) Bolivian government revised its constitution to acknowledge Bolivia as a 'multiethnic' and 'pluricultural' nation and the convention formed the basis for policies of decentralisation (1994-1995), which ultimately, in 2004 and 2009, led to the constitutional recognition of indigenous autonomy. ${ }^{134}$ In particular, this convention proved an important source for multi-centric norm construction in the process of constitutional mobilisation prior to enactment of the 2009 constitution. ${ }^{135}$ Notably, indigenous groups involved in constitution making at this time derived particular motivation and authority from this convention. ${ }^{136}$ Generally, the expectation that international human rights law would be solidified in the final constitution was common ground in the Constituent Assembly. This means, on one hand, that the political constitution of Bolivia that took effect in 2009 was already - to some degree - pre-figured and pre-legitimised by international law. The process of constitution making was conducted by groups asserting a constituent power, which, however intrinsically radical and diffuse, already

referring to human rights as part of the block, amongst which the Pact of San José is unequivocally included'.

130 See $n 122$ above.

131 See J. M. Pasqualucci, 'The Right to a Dignified Life (Vida Digna): The Integration of Economic and Social Rights with Civil and Political Rights in the Inter-American Human Rights System' (2008) 31 Hastings International and Comparative Law Review 1.

132 A. Brysk and C. Wise, 'Liberalization and Ethnic Conflict in Latin America' (1997) 32 Studies in Comparative International Development 76, 90, 96; N. Grey Postero, Now We Are Citizens. Indigenous Politics in Postmulticultural Bolivia (Stanford, CA: Stanford University Press, 2007) 51.

133 S. J. Anaya, 'International Human Rights and Indigenous Peoples: The Move Toward the Multicultural State' (2004) 21 Arizona Journal of International and Comparative 13, 24, 54.

134 Molina Saucedo, n 116 above, 201.

135 See S. Schavelzon, El nacimiento del estado plurinacional de Bolivia. Etnografía de una Asemblea Constituyente (La Paz: CLACSO, 2012) 160.

136 For critical comments on this see Lazarte, n 125 above, 69. 
enjoyed a certain inner-systemic legitimacy and formality, and which could be borrowed and consistently channelled from the international domain to provide quite stable reserves of legitimacy for the new political constitution. The process of constitution making was able to produce a constitution formed through the intense politicisation of plural constituencies in society because this politicisation was partly effected through the activation of already acceded rights, so that prior norms could be deployed both to authorise and to control the emergent political structure, and eventually to limit the demands of constituent actors. In fact, the standing of treaties in the 2009 Constitution ultimately meant that the political dynamics triggered by the long process of constitution making, especially those posing a risk of extreme centrifugalism or structural particularisation, remained within hard constraints, and tendencies threatening unmanageable dispersal of state authority were held in check. Most importantly, the doctrine of the block of constitutionality applied by the Constitutional Court meant that the national government could position laws within a normative hierarchy, and it could, where required, insist that specific legal acts have generally binding power, especially in relation to regional or indigenous customs: international human rights law became the foundation for determining some laws as possessing a higher, categorically public authority. Notably, therefore, international human rights laws were used to dictate overarching constraints within which communal self-government and indigenous justice could be exercised, and international law projected basic structural norms to connect society as a whole. ${ }^{137}$ The underlying political structure of society, in short, retained its origins in a normative design defined in part by international human rights norms.

In Bolivia, the judicial internalisation of international law, and especially international human rights law, into domestic law meant that a platform for highly complex, acentric and intensely contested patterns of political will formation could evolve, and multiple actors were able to assume a constituent role in forming the political system. On this basis, by any criterion, the Bolivian Constitution was established through, and still articulates, a deep, and at times highly experimental, politicisation of society. In this setting, notably, it is still widely argued that the formal-legal dimension of this constitution is underevolved. ${ }^{138}$ As mentioned, the elected government is only uncertainly distinct from a constituent power, and, with the support of the Constitutional Court, it has at times assumed the authority of a primary constituent actor, acting with limited regard for prior rights. ${ }^{139}$ To some degree, nonetheless, judicial institutions and international rights applied by them have played a core role in the process of political constitution making, and they have made it possible for this

137 See Bolivian Constitutional Court 0778 (2014). For comment see B. Clavero, 'Tribunal Constitucional entre estado plurinacional y pueblos indígenas: Un reto inédito en las Américas' Working Paper at http://www.egpp.gob.bo/files/materiales/Mod5Tribunal-Constitucional-enEstado-Plurinacional.pdf (last accessed 16 November 2015). In the relevant legislation, Ley de Deslinde Jurisdiccional (2010), indigenous communities and their judicial bodies are denied jurisdiction in 'crimes against international law'.

138 See Lazarte, n 125 above, 122; Balenciaga, n 108 above, 187, 223.

139 See n 119 above. 
process to occur within a basically cohesive political system. ${ }^{140}$ On one hand, international laws, especially human rights agreements and norms expressed in ILO 169, created a constitution-making situation, enabling different factions in society to project volitionally formed constitutional norms for collective inclusion, and to articulate shared points of orientation across broad social cleavages. International rights were thus assimilated in domestic society as principles to activate a multi-centric constituent power. At the same time, however, these same rights created a matrix in which judicial bodies could manage the inclusivity of the political system, and, in placing certain constraints on society's normative pluralism, they acted to balance and to mollify the political system's exposure to fragmentation caused by the social factions that it incorporated, and to authorise certain laws across society, as an underlying inclusionary structure. The 2009 Constitution has clearly led to a reinforcement of political institutions and, for all its flaws, it has given rise to a deepening of democracy, to a dramatic increase in minority inclusion, and to a clearly heightened penetration of the political system across society. ${ }^{141}$ The hybridisation of pluralised constituent power and judicially applied human rights law offers an important solution to the historically defining centrifugalism of Bolivian society, and it upholds a more pervasive inclusionary structure for society than its main precursor, the corporatist state created in 1952.

\section{CONCLUSION}

In many cases of contemporary constitution making, international human rights norms are judicially incorporated into national law making, often forming a judicial-constitutional order that weakens classical resources of political will formation. Generally, however, it is a sociological error to see this model of transnational judicial constitutionalism as anti-political. In fact, in most societies, this model acts as a corrective to the historical depletion of political structure, usually caused by the typical results of corporatist constitutionalism - especially inner-systemic privatism and hyperpoliticisation. As discussed above, before the intersection between national laws and international human rights laws, few societies had been able enduringly to abstract and to preserve a clearly and distinctively political structure. In most societies, it is only by virtue of the fact that they are accompanied, insulated, and internally checked by, international human rights norms that conventional patterns of political-systemic formation have become sustainable. In other words, internationally defined rights increasingly form the basis of differentiated political structure, and judicially enforced rights, often assimilated from the international legal domain, typically act as the elementary precondition for the existence of political constitutions, or of political structures tout court.

Despite this, there are signs in some societies that the rise of judicial power is beginning to promote hybrid or dialectical models of judicial/political

140 Molina Saucedo, n 116 above, 278.

141 Balenciaga, n 108 above, 57. 
constitutionalism, in which more conventional patterns of political structure building can be conducted in insulated, internally tempered fashion. This is usually typical of societies in which political inclusion has traditionally proved difficult, or even impossible. In such cases, internationally articulated rights norms are usually abstracted as the premise for political structure building because they permit governments to securitise institutions against risks posed by the mobilisation of their own political constituencies, they construct counterfactually generalised sources of constituent power, and they allow state institutions internally to support acts of inclusion across society. In such cases, the judicial implementation of human rights law norms has provided a paradoxical foundation for seemingly highly politicised processes of constitutional formation. In this respect, too, the conventional distinction and political and legal or judicial constitutionalism appears sociologically ill-constructed. 